\title{
Adsorption, Modeling, Thermodynamic, and Kinetic Studies of Methyl Red Removal from Textile-Polluted Water Using Natural and Purified Organic Matter Rich Clays as Low-Cost Adsorbent
}

\author{
Dalila Fkih Romdhane, ${ }^{1,2}$ Yosra Satlaoui,, ${ }^{1,3}$ Rawya Nasraoui, ${ }^{1,2}$ Abdelkrim Charef ${ }^{1}$, 1 \\ and Rim Azouzi ${ }^{1}$ \\ ${ }^{1}$ Georessources Laboratory, Research Center and Water Technologies of Borj Cedreya, Université de Carthage, Soliman, \\ Tunis, Tunisia \\ ${ }^{2}$ Faculté des Sciences de Tunis, Université de Tunis El Manar, Tunis, Tunisia \\ ${ }^{3}$ Faculté des Sciences de Bizerte-Zerzouna, Université de Carthage, Tunis, Tunisia
}

Correspondence should be addressed to Abdelkrim Charef; abdelkrim.charef@certe.rnrt.tn

Received 12 November 2019; Accepted 3 February 2020; Published 6 May 2020

Academic Editor: Shafaqat Ali

Copyright ( 12020 Dalila Fkih Romdhane et al. This is an open access article distributed under the Creative Commons Attribution License, which permits unrestricted use, distribution, and reproduction in any medium, provided the original work is properly cited.

\begin{abstract}
Clay minerals have large surface areas that contribute to their high adsorption capacity. Pure clays were often used. However, their prices remain expensive. However, the natural clay minerals that are locally available can have economic and environmental benefits for textile wastewater treatment. The tested natural clays had given low removal yields. Therefore, we wanted to test particular rich organic matter clay for adsorbing azo dye, which is a very toxic molecule. In order to make the use of this clay type have a better efficiency for removal of this dye from the polluted waters, the optimal conditions had been specified. The results indicated that advised conditions were as follows: $5 \mathrm{~min}$ was the contact time of dye-clay; the better adsorbent masses were $0.25 \mathrm{~g}$ and $0.5 \mathrm{~g}$ per $100 \mathrm{ml}$ solution for raw (ANb) and purified clays (ANp), respectively; the initial dye concentrations were $1 \mathrm{gL}^{-1}$ for raw clay and $50 \mathrm{mgL}^{-1}$ for purified clay; $\mathrm{pH}$ solution had any effect on the yield of dye removal only when raw clay was used; however, acid environment was advised when purified clay was the adsorbent and for the two tested clays about $20-30^{\circ} \mathrm{C}$ was the better solution temperature. X-Ray diffraction, Fourier transform infrared (FTIR) spectroscopy, and scanning electron microscopy (SEM) analysis confirmed that functional groups of clay adsorbed the dye. Langmuir maximum adsorption capacities of $\mathrm{ANb}$ and $\mathrm{ANp}$ were found to be $397 \mathrm{mgg}^{-1}$ and $132.3 \mathrm{mgg}^{-1}$ at $\mathrm{pH} 7$ and 5, respectively. Raw and chemically activated samples gave similar results. Adsorption of $\mathrm{ANb}$ and $\mathrm{ANp}$ data showed better agreement with the pseudo-second-order kinetic model. Thermodynamic parameters of the two adsorbents confirmed that the adsorption was endothermic $(\Delta \mathrm{H}>0)$ and spontaneous $\left(\Delta \mathrm{G}_{0}<0\right)$. Energy level was high when purified clay was used; however, it was significantly lower when the adsorbent was raw clay. Therefore, it was likely that adsorption by carbonates and organic matter involved small energy amounts. Comparing between these and other previous results, Jebel Louka natural clay type is better recommended for MR removal from textile wastewater, since the removal yield was about $98 \%$. Hence, this tested clay type could provide an alternative low-cost material that could be used in treatment of the textile wastewater rich in MR and the obtained adsorption model and desorption tests provided a background for pilot and industrial scale applications.
\end{abstract}

\section{Introduction}

Annual productions of the quantities and varieties of textile dyes are more and more important $[1,2]$ and have extensive industrial applications. These coloring molecules are often very toxic. Hence, these toxic chemical agents discharged into textile used water can often endanger the equilibrium of natural ecosystem [3] and have negative impacts on living organisms and environment [4-6]. We add that industrials prefer actually stable and hardly degradable colors. Hence, 
they generate molecules that are more complex and more difficult to eliminate from textile used water. Actually, there are more than 100,000 commercially existing dyes (azo dyes represent about $70 \%$ on weight of used dyes) and over one million tons of dyes are manufactured per year, of which $50 \%$ are textile dyes $[7,8]$. Therefore, during the dying process, significant amounts of toxic stable molecules were lost in used water [9]. Because of the molecules complexity and the affinity degrees of colorants to the textile fibers, the discharge of this water kind in the environment is very worrying today $[10,11]$. Hence, these pollutants of used water need to be well treated to obtain permissible concentrations before discharge.

Nowadays, many technologies are used to purify the contaminated water (e.g., $[12,13])$. These technologies permit the elimination of total impurities or decrease of their concentrations for having permissible limits. However, the cost remains high. Therefore, finding low-cost technologies and materials for textile wastewater treatment is still an objective for industrials.

Azo dye methyl red (MR) is among undesirable substances and is often used for coloring textile fibers. Various methods, processes, and materials were used for MR-dye elimination. Always, the principal objective has been finding the best conditions for extracting this dye from polluted wastewater (e.g., $[14,15])$. Treatment using biodecolorization with many simple sort and consortium of bacteria (mixture of bacteria) was tested [16-19]. Different chemical adsorbents such as $\mathrm{SiO}_{2}$-coated, $\mathrm{Fe}_{3} \mathrm{O}_{4}$ magnetic nanoparticles and modified iron oxide [20, 21] were tested. Natural minerals such as activated clay and carbon (e.g., [22-24]) were also used for MR elimination. But we are still looking for even cheaper adsorbents that can eliminate this pollutant type with more important yields.

Clay minerals have large surface areas and ionic characters that contribute to their high adsorption capacity [25]. Pure clays were often used. However, their prices remain expensive. Hence, the natural clay minerals that are locally available could have economic and environmental benefits for textile wastewater treatment. These raw materials have highly variable mineralogical compositions and proportions. This variability always imposes their investigation before their use as a potential alternative adsorbent for removal of dyes from textile wastewater (e.g., [26, 27]).

In Tunisia, clay minerals are abundant and have heterogenic composition. Many attempts were realized for utilizing clays as occurring adsorbents. These tested natural clays were not very efficient to eliminate important dye quantities (e.g., [28]). In order to search other qualities of materials, we are still looking for even cheaper adsorbents that can eliminate this pollutant type with more important yields. We proposed Jebel Louka clay type particularly rich in organic matter. Similar to the majority of natural materials, Jebel Louka clay type contains many minerals and essentially an important organic matter content that could adsorb important dye quantities. To be able to apply this natural clay in textile industry, it was always asked to have a strong and fast performance of dye elimination per volume unit. Therefore, the effects of some controllable parameters on the MR removal were studied.
The saturated clays with methyl red were often rejected in controlled and uncontrolled landfills. Therefore, it was important to perform desorption tests to quantify the binding energies of the MR-clay to assess the risk degree of rejection of polluted clays.

Hence, the objectives of this work were (1) to evaluate the adsorption behaviors of MR onto raw and purified Jebel Louka clay type, (2) to test the effects of contact time between the adsorbent and the aqueous solution of $\mathrm{MR}$, of adsorbent dose, of concentration of initial MR-ion, and of $\mathrm{pH}$ and temperature of aqueous solution, (3) to perform adsorption isotherms, adsorption kinetics, and thermodynamic parameters, (4) to identify and characterize the adsorption mechanism by X-ray diffraction (XRD), Fourier transform infrared (FTIR), and scanning electron microscopy (SEM), and (5) to evaluate the efficiency of using Jebel Louka clay type for MR removal.

\section{Materials and Methods}

2.1. Clay Sampling and Analysis. The used deposit is from Jebel Louka (Tunisia). The site is located in the extreme northwestern part of Tunisia. Its Lambert coordinates are E: 529590 and N: 412268 . It is a sedimentary series of Oligocene to Miocene age (Aquitanian, Burdigalian) [29, 30]. From this facies, about 5 composite samples were collected from five plots $(3 \times 3 \mathrm{~m})$ and from each point $10 \times 10 \times 20 \mathrm{~cm}$ volume of sediments was taken. Sampled sediments were homogenized and passed through $2 \mathrm{~mm}$ stainless steel sieves. All samples were lyophilized, milled with a mechanical grinder, and maintained at temperature about $4^{\circ} \mathrm{C}$ for programmed analyses.

For mineralogical characterization of total sediments (powder sample), raw and purified clays before and after MR adsorption were identified by X-ray diffraction (XRD) SIEMENS D-5000 type diffractometer with a scanning speed of $1^{\circ} 2 \theta \mathrm{min}$ and $\mathrm{Cu}-\mathrm{K} \alpha$ radiation $(40 \mathrm{kV}, 20 \mathrm{~mA})$ [31]. Semiquantitative estimation of detected minerals was based on peaks' area [32]. Granulometric study of sediment fraction $<63 \mu \mathrm{m}$ was performed using MAVERN X-ray grain size analyzer [33]. Major and trace element concentrations were determined with atomic adsorption Perkin Elmer spectrophotometer type AAS 200 associated with a graphite furnace and inductively coupled plasma-mass spectroscopy (ICP-MS). Clay $\mathrm{pH}$ was measured in clay: distilled water volume ratios of $[1: 2.5]$. Samples were stirred every 5 minutes, until the saturation period was reached $(0.5$ hours) [34]; $\mathrm{pH}$ was determined with $\mathrm{pH}$-meter LPH 230 T-type. Electric conductivity (EC) was measured in extracts soil: water ratio [1:5] [35] with a conduct meter model ORION 150. Total organic carbon (TOC) was analyzed by ANNE method [36]. Based on methylene blue spot and Bergaya and Vayer's methods, respectively (e.g., [37]), specific surface area (Ss) and the cation exchange capacity (CEC) values were determined. Casagrande method (e.g., [38]) was applied for the determination of samples Atterberg limits. Experimental error was about $\pm 3 \%$.

In order to purify natural representative sample (ANb) of Jebel Louka, distilled water and $\mathrm{H}_{2} \mathrm{O}_{2}$ were used to remove 
organic matter $(\mathrm{OM})$. Then, hydrochloric acid $(10 \%)$ was added while controlling $\mathrm{pH}$ to dissolve the carbonate fractions. Sample was washed with distilled water in order to rid the excess acid and to allow the deflocculating of clay. Finally, the suspension was centrifuged at $2500 \mathrm{rpm}$ for 10 minutes to obtain the pure Jebel Louka clay fraction (ANp).

UV-Visible spectrophotometry analysis using a Perkin Elmer Lambda 25 Spectrophotometer, at wavelengths between 200 and $800 \mathrm{~nm}$, was used to measure the remaining MR in separated suspension phase and FTIR spectra of the methyl red (MR) dye and raw and purified clay before and after adsorption using wavelengths of $\lambda=455 \mathrm{~nm}$.

Appearance and morphology of the adsorbent surface before and after adsorption of MR-dye were carried out with a SEM (scanning electron microscope JEOL JSM 5400).

2.2. Adsorbate. Methyl red (dimethyl amino-4 phenylazo- 2 benzoic acid or diamino- 4 phenylazo- 2 carboxybenzene) is a monoazo anionic dye (Table 1).

2.3. Adsorption Experiments. Adsorption experiments were carried out by adding three adsorbent dosages ranging from $0.25 \mathrm{~g}$ to $1 \mathrm{~g}$ with a constant dye concentration $\left(750 \mathrm{mgL}^{-1}\right)$ in aqueous solution $(100 \mathrm{ml})$ at temperature of $25^{\circ} \mathrm{C}\left( \pm 2^{\circ} \mathrm{C}\right)$ and $\mathrm{pH}$ 9. The colored solutions at specified concentrations were put in glass bottles. After shaking at a fixed speed of $450 \mathrm{rpm}$ to attain equilibrium state, the liquid-solid phases were separated by centrifuging at a rate of $3000 \mathrm{trs} \mathrm{min}^{-1}$ for $20 \mathrm{~min}$.

Effects of adsorbent doses $\left(0.25,0.5,1 \mathrm{gL}^{-1}\right)$, contact times $(0$ to 120 minutes $), \quad M R$ concentrations $\left(30-1000 \mathrm{mgL}^{-1}\right), \mathrm{pH}$ (3 to 11 ), and temperatures $\left(20^{\circ} \mathrm{C}\right.$, $30^{\circ} \mathrm{C}$, and $40^{\circ} \mathrm{C}$ ) on dye removal were investigated. In Table 2 all chemical reagents and their concentrations used in the experimental study were detailed. We note that the purity degree of all reagents is about 99.7 .

In order to ensure the reproducibility of obtained results, all analyzed parameters collected from batch experiments tested onto raw, purified, and activated clays of Jebel Louka were carried out three times under identical conditions. The reproducible results were only considered. Statistical analysis of the data was implemented using SPSS Statistics 21 software.

The adsorbed MR quantity (qe, $\mathrm{mgg}^{-1}$ ) at equilibrium state was calculated by the following equation:

$$
\mathbf{q}_{\mathbf{e}}=\frac{\left(\mathbf{C}_{0}-\mathbf{C}_{\mathbf{r}}\right) * \mathbf{V}}{\mathbf{m}}
$$

where $\mathrm{C}_{0}\left(\mathrm{mgL}^{-1}\right)$ is initial dye concentration, $\mathrm{C}_{\mathrm{r}}\left(\mathrm{mgL}^{-1}\right)$ is residual concentration at equilibrium $\left(\mathrm{mgL}^{-1}\right), \mathrm{V}$ is volume of solution (l), and $\mathrm{m}$ is mass of adsorbent ( $\mathrm{g}$ ).

In order to investigate adsorption process of methyl red (MR) dye, infrared spectroscopy was carried out before and after adsorption. ANb and ANp were mixed with spectroscopically pure $\mathrm{KBr}$ ( $2 \mathrm{mg}$ of clay was mixed with $200 \mathrm{mg}$ of $\mathrm{KBr})$. Infrared spectra were obtained by Fourier infrared spectroscopy [42] using Bruker FTIR-2000 spectrometer
TABLE 1: Characteristics of methyl red (MR).

Chemical structure

Chemical formula

Change range of $\mathrm{pH}$

$\lambda_{\max }$

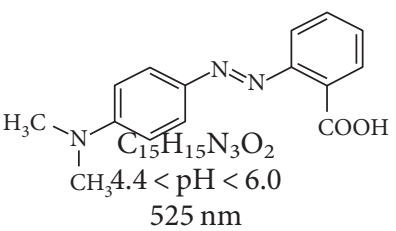

Methyl red (MR) is soluble in water, ethanol, glacial acetic acid, and ether [39]. The group of azo dyes is characterized by the presence of $-\mathrm{N}=\mathrm{N}$ - bond and synthesized by primary amine $[40,41]$

TABLE 2: Chemical reagents used in experimental essays of adsorption of MR dye.

\begin{tabular}{lc}
\hline Chemical reagents & Concentrations \\
\hline $\mathrm{MR}$ & $30,50,250,500,750$, and $1000 \mathrm{gL}^{-1}$ \\
$\mathrm{HCl}$ & $1.1 \mathrm{~N}, 0.5 \mathrm{~N}$, and $3 \mathrm{~N}$ \\
$\mathrm{H}_{2} \mathrm{SO}_{4}$ & $2 \mathrm{~N}$ \\
$\mathrm{NaOH}$ & $1 \mathrm{M}$ \\
$\mathrm{H}_{2} \mathrm{O}_{2}$ & $30 \%$ \\
\hline
\end{tabular}

with reflection mode at a $4 \mathrm{~cm}^{-1}$ resolution in the $400-4000 \mathrm{~cm}^{-1}$ range.

2.4. Modeling. Adsorption isotherms described the equilibrium processes $[43,44]$. They were also used to determine clayfixing capacities of methyl red (MR) and adsorption type. Langmuir, Freundlich, and Dubinin-Radushkevich adsorption models based on experimental data were used to identify isotherms of various adsorption systems. Thermodynamic parameters such as free energy $\left(\Delta \mathrm{G}^{\circ}\right)$, standard enthalpy $\left(\Delta \mathrm{H}^{\circ}\right)$, and standard entropy $\left(\Delta S^{\circ}\right)$ were calculated. Pseudo-first-order and pseudo-second-order models were implicated to precise adsorption kinetic model of MR into tested Jebel Louka clay.

\section{Results and Discussion}

3.1. Adsorbent Characterization. The analyzed parameters of natural clay were granulometry, $\mathrm{pH}$, electric conductivity (EC), cation exchange capacity (CEC), specific surface area (Ss), and carbonates $\left(\mathrm{CaCO}_{3}\right)$ and organic matter (TOC) contents. Only arithmetic mean, maximum, minimum, and standard deviation of statistical analysis were presented in Table 3.

Purified clay sample has more acid $\mathrm{pH}$ (4.7) compared to raw material. EC shows that purified clay ANp is more salty (0.1) than ANb clay (0.4). Natural clay is relatively rich in organic matter (about 7.5\%). Clay treatments have improved particles specific surface areas (Ss) (from 39.7 to $39.2 \mathrm{~m}^{2} \mathrm{~g}^{-1}$ ) and decreased cation exchange capacities (from 26.7 to 21.4 meq100 $\mathrm{g}^{-1}$ ) and electric conductivities (from 0.4 to $0.1 \mathrm{mScm}^{-1}$ ) (Table 2). This clay type is considered anomaly rich in organic matter $(8.2 \%)$.

Principal minerals of natural clay (ANb) are kaolinite, illite, quartz, and $\mathrm{CaCO}_{3}$. The percentages of dolomite and sulfate are lower than $2 \%$, that is, the XRD (X-ray diffraction) detection limit. Thus, they are observed only by microscopic study. Mean values of granulometric and physicochemical analysis indicated that Jebel Louka natural clay is dominated by fine fraction (65.8\%) that is composed 
TABLE 3: Statistic values of the maximum physiochemical parameters of raw and purified clays of Jebel Louka.

\begin{tabular}{lcc}
\hline & ANb & ANp \\
\hline $\mathrm{pH}$ & $6.3(5.8-6.6)$ & $4.8(4.7-4.8)$ \\
& $\pm 0.3^{* * *}$ & $\pm 0.06^{* *}$ \\
$\mathrm{EC}\left(\mathrm{mScm}^{-1}\right)$ & $0.4(0.4-0.5)$ & $0.3(0.1-0.2)$ \\
& $\pm 0.01 *$ & $\pm 0.44^{*}$ \\
$\mathrm{TOC} \%$ & $8.3(9.1-7.6)$ & 0 \\
& $\pm 0.13^{* *}$ & \\
$\mathrm{CaCO}_{3} \%$ & $2.5(2.9-2.0)$ & 0 \\
& $\pm 0.03^{* *}$ & $21.5(21.4-21.5)$ \\
$\mathrm{CEC}\left(\mathrm{méq} 100 \mathrm{~g}^{-1}\right)$ & $26.7(26.7-26.9)$ & $\pm 0.04^{*}$ \\
& $\pm 0.10^{*}$ & $39.2(39.1-39.3)$ \\
Ss $\left(\mathrm{m}^{2} \mathrm{~g}^{-1}\right)$ & $37.7(37.6-37.9)$ & $\pm 0.07^{* * *}$ \\
\hline
\end{tabular}

Mean (minimum-maximum); \pm SD : standard deviation; ${ }^{*} p<0.05$; ${ }^{* *} p<0.01 ;{ }^{* * *} p<0.001$.

of $50.5 \%$ silt and $15.3 \%$ of clay. Proportion of sandy fraction is $32.43 \%$.

Chemical composition of raw and purified clays, as shown in Table 4, is dominated by silica ( $54.8 \%$ and $57.1 \%)$, alumina (18.2\% and $22.7 \%)$, and high iron quantity $(7.2 \%$ and $11.8 \%$ ). This clay type is distinguished by the high yield of waste fire that confirms its high percentage of organic matter content.

3.2. Adsorption Characteristics. In order to characterize adsorption process of MR onto Jebel Louka clay, we discussed effects of adsorbent dose, contact time, initial MR concentration, $\mathrm{pH}$, and temperature on clay capacity of dye removal from tested solution.

3.2.1. Effects of Adsorbent Dosage and Contact Time. $0.25 \mathrm{~g}$ of clay was separately added to $100 \mathrm{~mL}$ solution with variable initial methyl red concentrations ranging from $30 \mathrm{mgL}^{-1}$ to $1 \mathrm{gL}^{-1}$, at a fixed $\mathrm{pH} 9$. After shaking of colored solutions in glass bottles at a fixed speed $(450 \mathrm{rpm})$ to attain equilibrium state, the liquid and solid phases were separated by centrifugation.

Adsorbed amount of dye increased for natural (ANb) and purified clays (ANp). It was more important for $\mathrm{ANb}$ $\left(262 \mathrm{mgg}^{-1}\right)$ than for ANp $\left(81 \mathrm{mgg}^{-1}\right)$. Amount of adsorbed dye was inversely proportional to clay mass. For the two cases, adsorption process was rapid during the first 5 minutes. Continued agitation for 115 minutes did not allow an adsorption of additional quantities of MR on natural clay. However, after $5 \mathrm{~min}$, sorption became less efficient for ANp. The highest decrease was for the smaller clay amount. Thus, contact time needed to reach equilibrium conditions was only $5 \mathrm{~min}$ for three tested quantities $(0.25 \mathrm{~g}, 0.5 \mathrm{~g}$, and $1 \mathrm{~g})$ of natural clay. This quickly obtained equilibrated state was probably due to high availability of active sites on clay surface (Figure 1).

It was expected that the increase of clay amount promoted an increase in number of active sites [45] and consequently adsorbed quantity of MR. However, the increase of clay mass $(0.5$ and $1 \mathrm{~g})$ induced a decrease in adsorbed quantity of MR per mass unit of clay minerals. Therefore, small amount of adsorbent favored ease access of MR to adsorption sites. With increasing adsorbent quantity, MR molecule found difficulty to reach active sites of clay (e.g., [46]). Therefore, we suggested that the overcrowding phenomenon and agglomerations of clay particles created with large amounts of adsorbent had reduced total adsorption areas. Consequently, the decrease of the ratio "clay mass/ solution volume" avoided creation of physical and chemical phenomena, discussed in the above section, that promoted MR adsorption [47]. For purified clay, probably the long shaking provoked desorption of some MR quantity that did not have a hard relation with adsorbent. However, for raw clay, this desorbed quantity was readsorbed onto other minerals and particularly onto carbonate and organic matter.

Saxena and Sharma [48] showed similar results while they were studying the removal of MR by Guar Gum (GG) Powder. They confirmed that when adsorbent quantities increased, MR molecule found difficulty to reach active sites of clay and the increase in the adsorbate dose led also to a decrease in the adsorbed amount of dye.

3.2.2. Effect of Initial Dye Concentration. Effect of initial azo dye concentration on adsorption capacity of natural ( $\mathrm{ANb})$ and purified (ANp) clays was investigated in the range from $30 \mathrm{mgL}^{-1}$ to $1 \mathrm{gL}^{-1}$. It was studied at a fixed shaking speed of $450 \mathrm{rpm}$, dye solution of $100 \mathrm{~mL}$, clay mass of $0.25 \mathrm{~g}$, and ambient temperature about $25^{\circ} \mathrm{C}$.

Adsorption capacities of $\mathrm{ANb}$ and $\mathrm{ANp}$ increased with increase of initial concentration of dye. The highest adsorbed quantity (qe) of dye was obtained with $1 \mathrm{gL}^{-1}$ of MR initial concentration (Figure 2). The equilibrium state that marked the saturation of active sites of adsorbents was reached at the end of the first 5 minutes of the experience period [47]. After $10 \mathrm{~min}$ of shaking, due to the resistance of dye uptake, we had an adsorption decrease of MR as long as mass transfer driving forces increased [49].

Laabd et al. [50] showed also similar results while studying the removal of monoazoic dye by polyaniline. Sure enough, the increase of initial dye concentration led to an increase in the adsorbed amount of dye.

3.2.3. Effect of $\mathrm{pH}$. $\mathrm{pH}$ of aqueous solution is an important factor in any atom or molecule adsorption. In this study, $0.25 \mathrm{~g}$ of sorbent was mixed in glass bottles with a solution of $1 \mathrm{gL}^{-1}$ of MR and shacken at a fixed speed (450 rpm) to attain equilibrium state. The $\mathrm{pH}$ solution values ranging from 3 to 11 were adjusted by either $1 \mathrm{M} \mathrm{HCl}$ or $1 \mathrm{M} \mathrm{NaOH}$ solutions. With continuous shaking, many aliquots of $5 \mathrm{ml}$ were taken after different contact times (every 5 minutes at first and then every 20 minutes).

Removal batch experiments of MR with natural clay indicated that all tested $\mathrm{pH}$ offered favorable conditions for uptake of this dye, since slight qe variations were observed (between 364 and $387 \mathrm{mgg}^{-1}$ ) (Figure 3). Therefore, we suggested that different minerals of natural clay had probably different surface charge characteristics. It was probable 
TABLE 4: Chemical composition of raw and purified clays of Jebel Louka.

\begin{tabular}{lccccccccc}
\hline Component weight (\%) & $\mathrm{SiO}_{2}$ & $\mathrm{Al}_{2} \mathrm{O}_{3}$ & $\mathrm{FeO}_{3}$ & $\mathrm{MgO}$ & $\mathrm{K}_{2} \mathrm{O}$ & $\mathrm{CaO}$ & $\mathrm{SO}_{3}$ & $\mathrm{Na}_{2} \mathrm{O}$ & Fire waste \\
\hline $\mathrm{ANb}$ & 54.8 & 18.2 & 7.2 & 0.5 & 1.72 & 2.7 & 1.3 & 0.11 & 12.75 \\
$\mathrm{ANp}$ & 57.1 & 22.7 & 11.78 & 0.06 & 2.69 & 0.3 & 0.32 & 0.76 & 3.68 \\
\hline
\end{tabular}

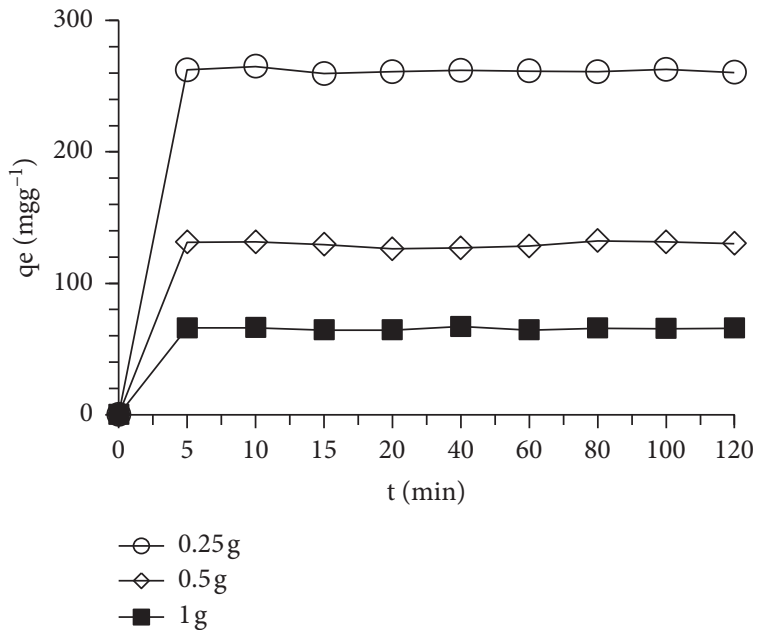

(a)

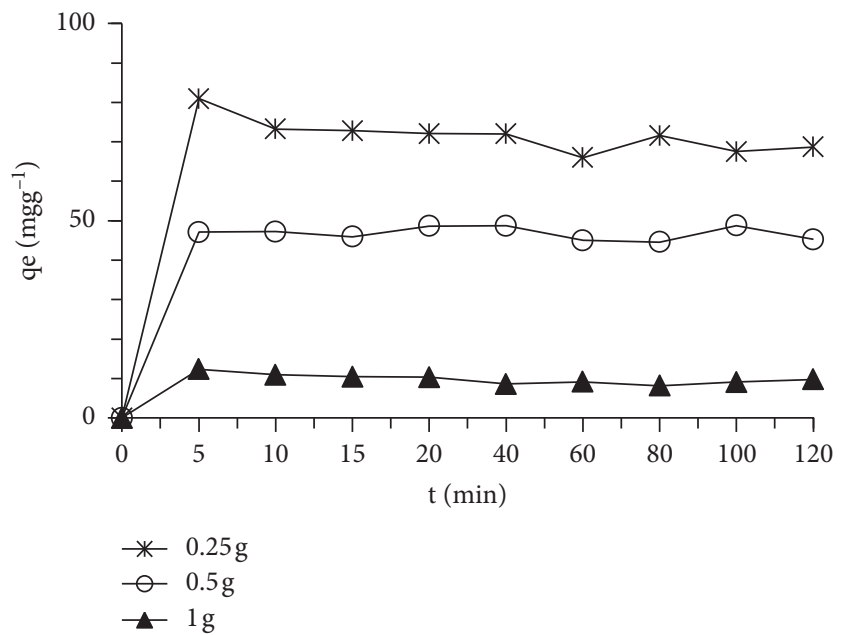

(b)

Figure 1: Effect of adsorbent dose and contact time on raw (a) and purified (b) clays.

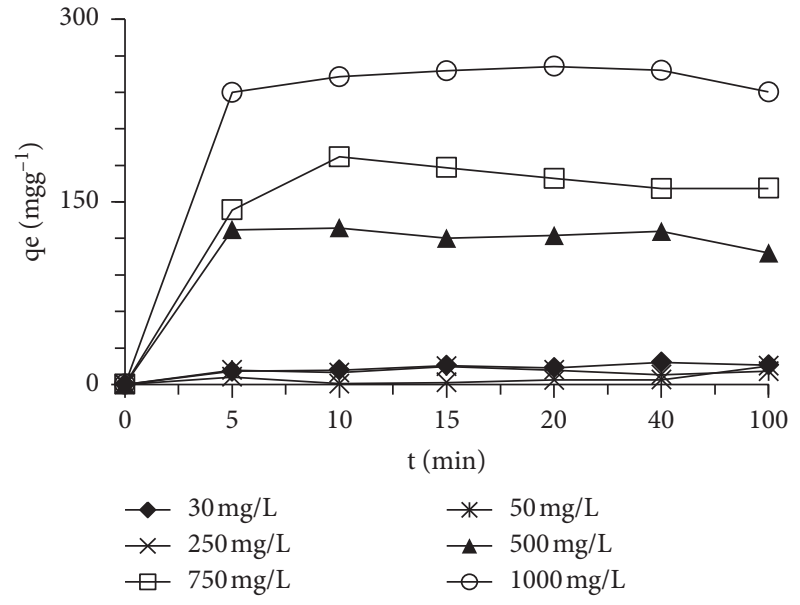

(a)

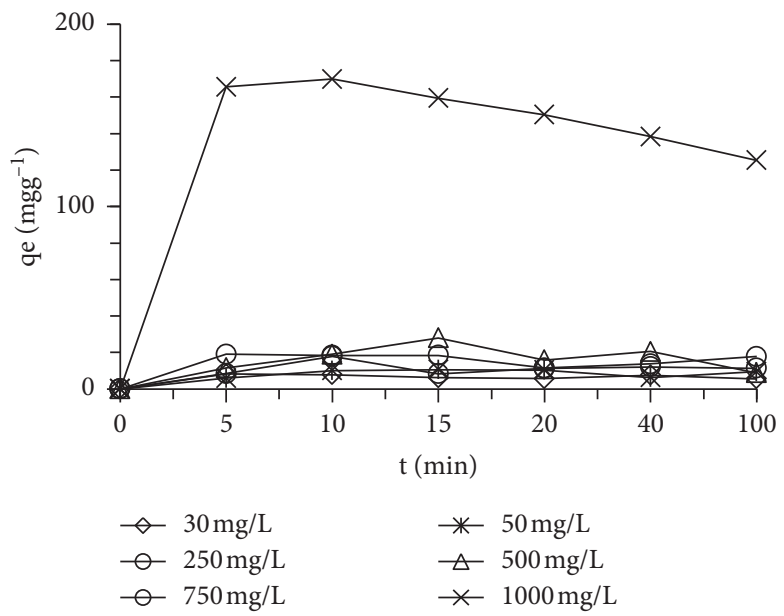

(b)

FIGURE 2: Effect of initial dye concentration on adsorbed quantities onto raw (a) and purified (b) clays.

that dominant mineral that fixed MR varied with the change of solution $\mathrm{pH}$. Hence, overall, the adsorbed quantity of MR remained almost stable. The low fluctuation of the isotherms observed supports this explanation (Figure 3).

Adsorption capacity of purified clay showed a gradual drop of retained amount of MR per mass unity of clay with $\mathrm{pH}$ increase. At $\mathrm{pH} 3\left(376 \mathrm{mgg}^{-1}\right)$ and $5\left(396 \mathrm{mgg}^{-1}\right)$, the uptake of MR was appreciable. However, at basic $\mathrm{pH}$ $(\mathrm{pH}=11)$, the removed quantity of $\mathrm{MR}$ was only about $66 \mathrm{mgg}^{-1}$ (Figure 3). Adsorption efficiency at a very acid $\mathrm{pH}$ was also signaled by other previous studies (e.g., [51]). Acid $\mathrm{pH}$ could change several characteristics of adsorbent such as surface charges and ionization and dissociation degree of functional groups from its active sites. It could also affect the dissociation of functional groups of adsorbents and the affinity to adsorbents [52] and an electrostatic attraction could exist between surface of the adsorbent and adsorbate molecules [46]. However, adsorption capacity decrease at basic $\mathrm{pH}$ was mostly due to the dominance of the negative charges at the surface of the adsorbent or due to the low competition between $\mathrm{OH}^{-}$and dye anions in basic $\mathrm{pH}$ [53-55].

3.2.4. Temperature Effect. Effect of temperature on adsorption processes is always mentioned in several researches $[56,57]$. Batch adsorption experiments were carried out with 


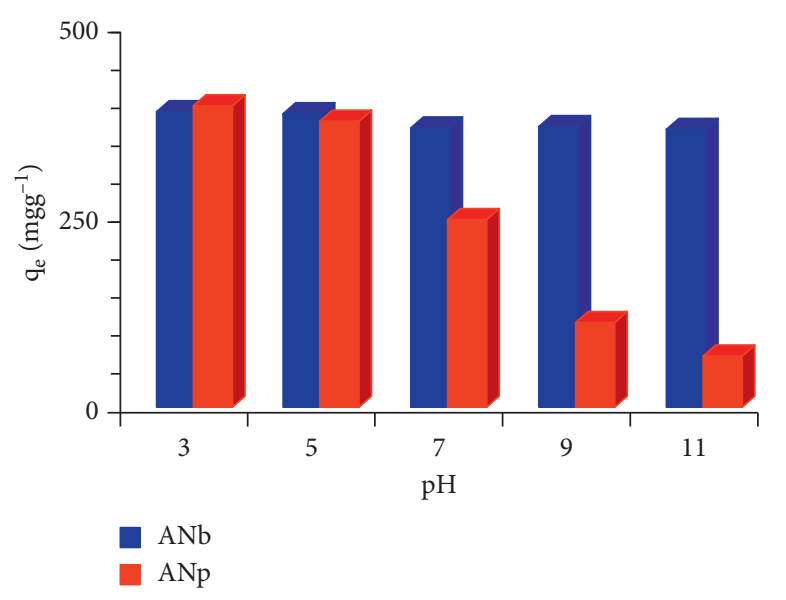

FIgURE 3: Effect of variation of $\mathrm{pH}$ of aqueous solution on raw $(\mathrm{ANb})$ and purified (ANp) clays.

$100 \mathrm{~mL}$ solutions of $1 \mathrm{gL}^{-1} \mathrm{MR}$ with $0.25 \mathrm{~g}$ of adsorbent and at 20,30 , and $40^{\circ} \mathrm{C}$ (commonly registered in arid and semiarid countries).

Obtained experimental results showed that there was no great difference of MR removal at the three tested temperatures for natural clay (Figure 4). Hence, temperature had a small influence on adsorption capacity of natural clay. It was possible that quartz, small fractions of carbonates, sulfate, and the relatively high amount of organic matter had equilibrated the energetic balance and had favored adsorption of dye amounts not fixed by pure clay fractions.

However, an important reduction of adsorption capacities of purified clay with temperature increases was observed (Figure 4). In many cases, with increasing temperatures, the adsorption capacities of adsorbents increased by an increase of diffusion rate of MR across external boundary layer and in internal pores of clay minerals. It was also possible that the increase of temperature increased solubility of sorbent that might acquire sufficient energy to undergo an interaction with active sites [58]. Thus, ambient temperature changes could change the adsorbent capacity [44]. However, for Jebel Louka sorbent, temperature increases led to decreases in its adsorption capacity. The same phenomenon was also observed in other previous studies [59-61]. It was considered that the increasing temperature probably produced a swelling effect within the internal structure of absorbent. This structure variation probably had further effects on the penetration of the large MR molecules [62]. This decrease could be also explained by the exothermicity and spontaneity of adsorption process and by the weakening of bonds between dye molecules and active sites of adsorbents for high temperatures (e.g., [63]). In addition, we think that with acidic $\mathrm{pH}$ of pure clay fraction temperature had an important effect on the adsorption process.

3.3. Adsorption Characterization. To characterize MR adsorption, clay adsorption tests were done under optimal batch conditions which were clay mass, initial dye concentration, contact time, $\mathrm{pH}$, and temperature.

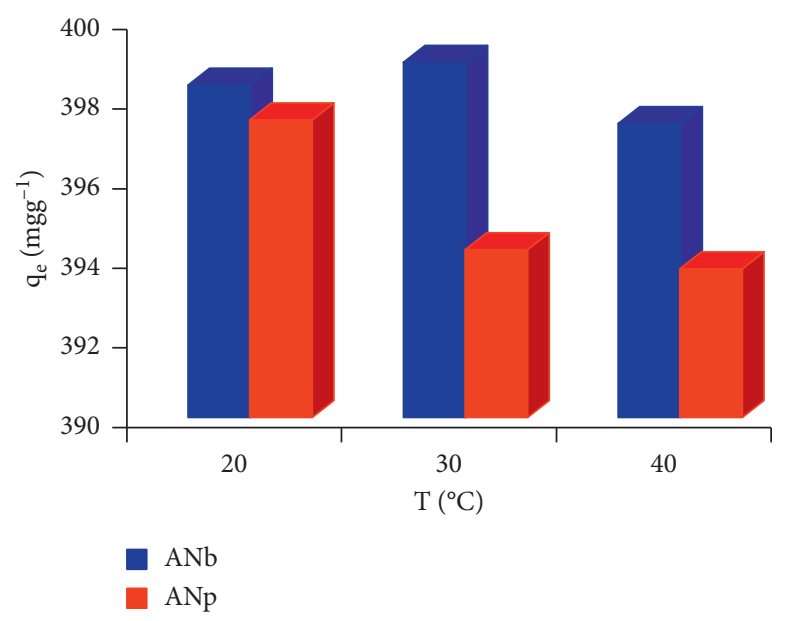

FIGURE 4: Effect of temperature on raw (ANb) and purified (ANp) clays.

3.3.1. DRX Characterization. To highlight the intercalation of MR molecules on clay minerals and to estimate their influence on structure and mineralogy of adsorbate clay, qualitative mineralogical study dye by diffraction X-rays was also done after MR adsorption. Comparison of $\mathrm{ANb}(\mathrm{AB})$ clay diffractograms before and after adsorption (AB-MR) showed an increase in reticular distance of phyllosilicate (located at 4.47 ) and a slight increase in quartz peak characteristic (located at 3.35) (Figure 5). These variations were related to an increase in secondary peaks of clay minerals and minerals.

Diffractograms of purified clay ANp before (AP) and after (AP-MR) adsorption showed some variations such as an increase in the reticular distance of Kaolinite (Figure 6). These findings confirmed the intercalation of MR molecules on the surface of clay materials and in the interfoliar space. Therefore, adsorption of MR on clay surface of Jebel Louka was not a physical process, but it was a chemisorption that was produced by exchange between ions of dye and clay of interfoliar layer. Electrostatic forces probably produced this clay-color interaction [64].

3.3.2. FTIR Spectra Characterization. The identification of Fourier transform infrared (FTIR) spectra was obtained through John Coates proposition [65]. Group frequencies and functional groups of MR dye were resumed in Table 5. The bands obtained at $3570 \mathrm{~cm}^{-1}$ and $3200 \mathrm{~cm}^{-1}$ indicated the hydroxyl group (O-H stretch) and normal "polymeric" $\mathrm{O}-\mathrm{H}$ stretch, respectively. The primary, secondary, and tertiary amine stretch were obtained at $3400.22 \mathrm{~cm}^{-1}$, $1606 \mathrm{~cm}^{-1}, 1374.43 \mathrm{~cm}^{-1}$, and $1210.06 \mathrm{~cm}^{-1}$ respectively. The methyl-amino stretch $\left(\mathrm{N}-\mathrm{CH}_{3}\right)$ was obtained at $2820.13 \mathrm{~cm}^{-1}$ and the open-chain azo $(-\mathrm{N}=\mathrm{N}-)$ at $1630 \mathrm{~cm}^{-1}$. In addition, the simple C-H stretching vibration and aromatic and alkyne $\mathrm{C}-\mathrm{H}$ bend were obtained at $2820.34 \mathrm{~cm}^{-1}, 672 \mathrm{~cm}^{-1}$, and $683 \mathrm{~cm}^{-1}$. The conjugated and $\mathrm{C}=\mathrm{C}$ stretch vibration were obtained at $1680 \mathrm{~cm}^{-1}$ and $1606 \mathrm{~cm}^{-1}$, respectively. Also, the C-O-C stretch was indicated at $1151 \mathrm{~cm}^{-1}$. The $-\mathrm{COOH}$ bending vibrations for carboxylic acid occurred between 1780 and $1714 \mathrm{~cm}^{-1}$. 


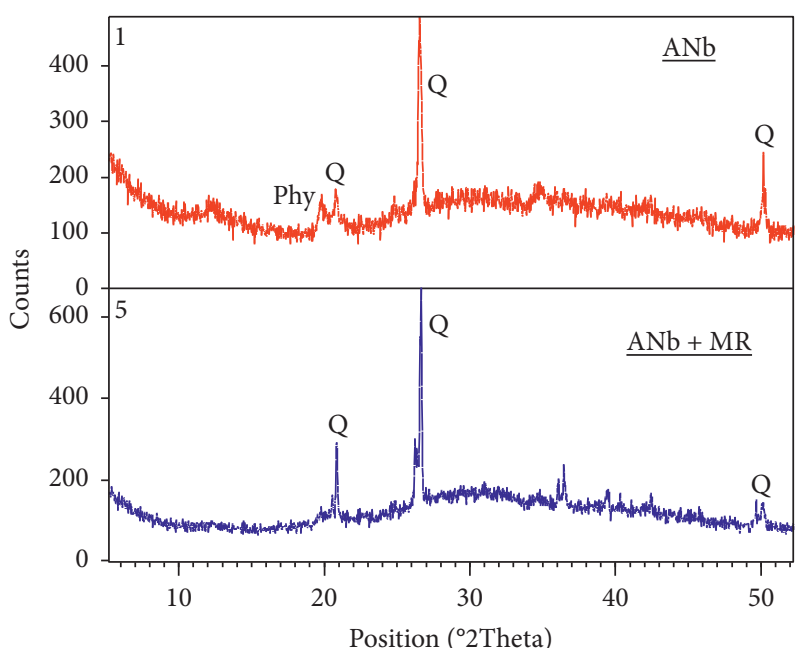

FIGURE 5: XRD spectra of raw clay before $(A B)$ and after $(A B+M R)$ MR adsorption.

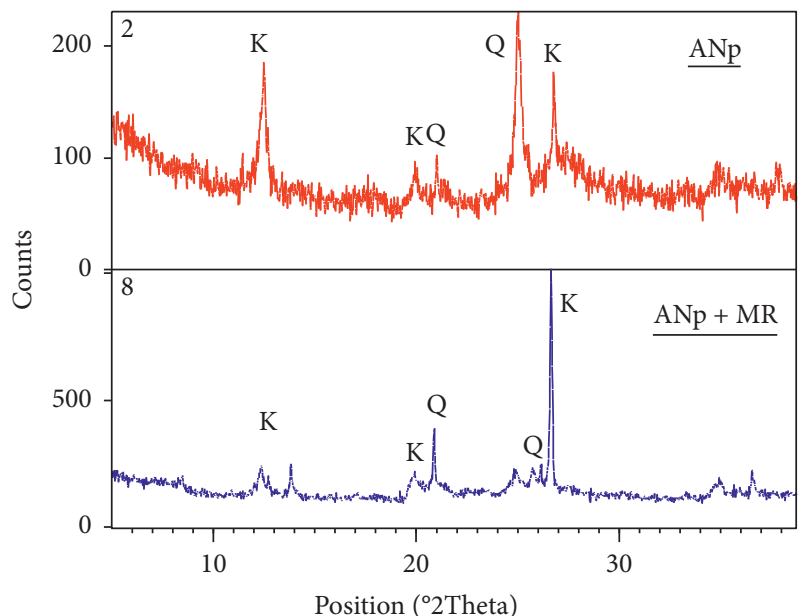

FIGURE 6: XRD spectra of purified clay before (AP) and after $(\mathrm{AP}+\mathrm{MR})$ adsorption.

TABLE 5: Group frequencies $\left(\mathrm{cm}^{-1}\right)$ and functional groups of the methyl red.

\begin{tabular}{|c|c|}
\hline $\begin{array}{l}\text { Group frequency } \\
\left(\mathrm{cm}^{-1}\right)\end{array}$ & Functional group \\
\hline $3570-3200$ & Hydroxy group, H-bonded O-H stretch \\
\hline $3400-3200$ & Normal "polymeric" O-H stretch \\
\hline $3400-3380$ & $\begin{array}{c}\text { Primary amino: aliphatic primary amine N- } \\
\text { H stretch }\end{array}$ \\
\hline $3000-2800$ & $\begin{array}{l}\text { Simple C-H stretching vibrations for } \\
\text { saturated aliphatic species }\end{array}$ \\
\hline $2820-2780$ & Methyl-amino, N-CH3, C-H stretch \\
\hline $1780-1714$ & Carboxylic acid $(-\mathrm{COOH})$ \\
\hline $1630-1575$ & Open-chain azo $(-\mathrm{N}=\mathrm{N}-)$ \\
\hline $1650-1550$ & Secondary amine, $\mathrm{NH}$ bend $(>\mathrm{N}-\mathrm{H})$ \\
\hline $1680-1601$ & Conjugated $\mathrm{C}=\mathrm{C}, \mathrm{C}=\mathrm{C}$ stretch vibration \\
\hline $1360-1280$ & $\begin{array}{c}\text { Aromatic secondary and tertiary amine } \mathrm{CN} \\
\text { stretch }\end{array}$ \\
\hline $1210-1150$ & Tertiary amino compound \\
\hline $1151-1070$ & C-O-C stretch, alkyl-substituted ether \\
\hline $900-670$ & Aromatic $\mathrm{C}-\mathrm{H}$ out of plane bend \\
\hline $680-610$ & Alkyne C-H bend \\
\hline
\end{tabular}

Adsorption of azo dye (MR) was controlled also by using the FTIR spectroscopy. The comparison between FTIR spectra of natural clay after adsorption (ANb $+\mathrm{MR})$ indicated a clear difference, which confirmed the adsorption of dye (Figure 7). The spectrum of $\mathrm{ANb}+\mathrm{MR}$ indicated the disappearance of the stretching vibrations between 3500 and $3200 \mathrm{~cm}^{-1}$, between 1800 and $1250 \mathrm{~cm}^{-1}$, and between 692 and $683 \mathrm{~cm}^{-1}$. The removal of those stretching bends confirmed the adsorption process that happened for the MR dye. The bending vibrations between 1110 and $1020 \mathrm{~cm}^{-1}$ displayed the organic siloxane and silicone ( $\mathrm{Si}-\mathrm{O}-\mathrm{Si}$ ).

The FTIR spectrum of purified clays after adsorption $(\mathrm{ANp}+\mathrm{MR})$ was mentioned in Figure 8. The appearance of bending vibrations at 1603,1375 , and $1080 \mathrm{~cm}^{-1}$ indicated the presence of carboxylic acid, aromatic tertiary amine, and $\mathrm{Si}-\mathrm{O}$, respectively. These results confirmed the partial adsorption of azo dye.

The FTIR spectrum results confirmed that minerals and organic matter of natural clay had a more adsorption capacity compared to pure clay fraction.

3.3.3. SEM Characterization. SEM micrograph ANb before adsorption showed the clay grains and leaflets lamellar structures and aggregates were heterogeneous (different sizes and shapes and rough appearance of particles) (Figure 9(a)). However, after adsorption, the micrograph showed a homogeneous surface indicating that clay surface was covered with the MR-dye molecules. Therefore, we had a disappearance of pores and spaces between clay aggregates (Figure 9(b)).

Surface morphology of ANp was determined by SEM (Figures 10(a) and 10(b)) and showed the SEM micrographs of ANp sample before and after adsorption of MR dye.

The purified material (ANp) had pores and spaces between clay aggregates that were well apparent. Aggregates were very heterogeneous and presented in platelet forms of sticks with irregular contours. Lamellar structure was also observed (Figure 10(a)).

The scanning view of ANp after adsorption showed homogeneous surface morphology that was covered with MR-dye molecules (Figure 10(b)).

These results confirmed physisorption model and this dye could be easily liberated from saturated clays during adsorption process.

Similar results were observed by Saxena and Sharma [48]. Their SEM figures showed that GG (Guar Gum) was covered with dye molecules and presented a rough surface morphology.

3.4. Adsorption Isotherms. Adsorption isotherms that describe adsorbed MR (qe) onto tested clay at equilibrium condition (Ce: concentration of solute in $\mathrm{mgL}^{-1}$ at equilibrium), constant temperature, and $\mathrm{pH}$ [66] were proposed. Several equilibrium adsorption isotherm equations were available. Langmuir, Freundlich, and Dubinin-Radushkevich models (D-R) were applied to understand the mechanism of MR adsorption by tested clays. 


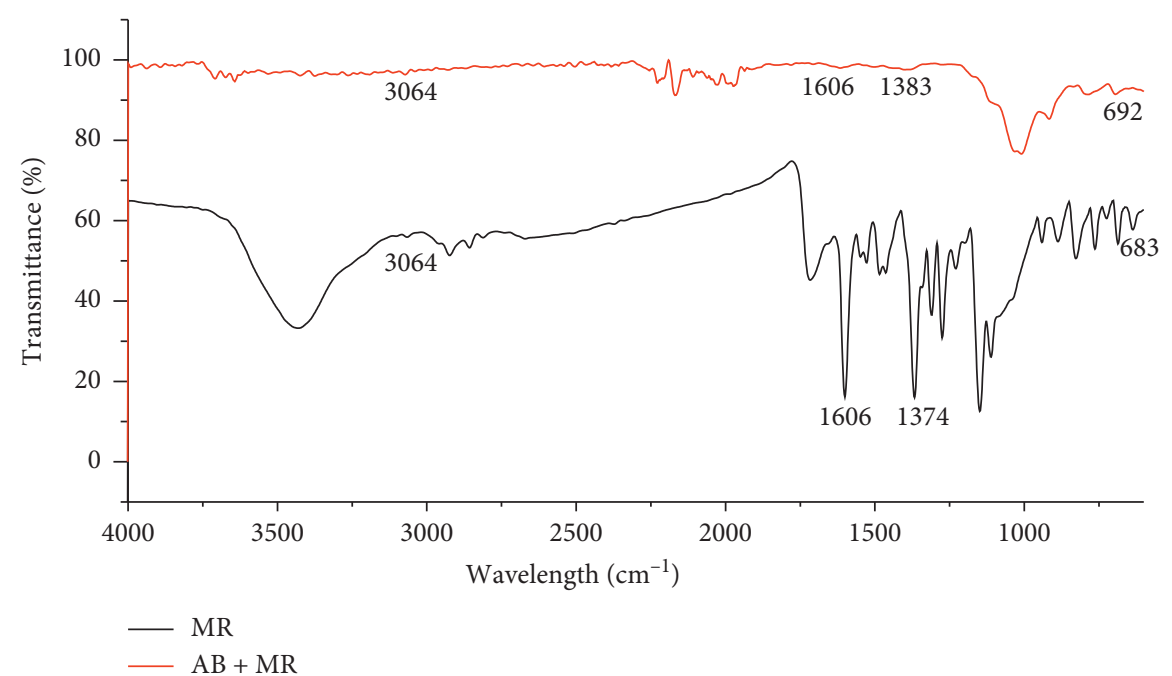

FIGURE 7: FTIR spectra of methyl red (MR) dye and after its adsorption by raw clay ( $\mathrm{MR}+\mathrm{ANb})$.

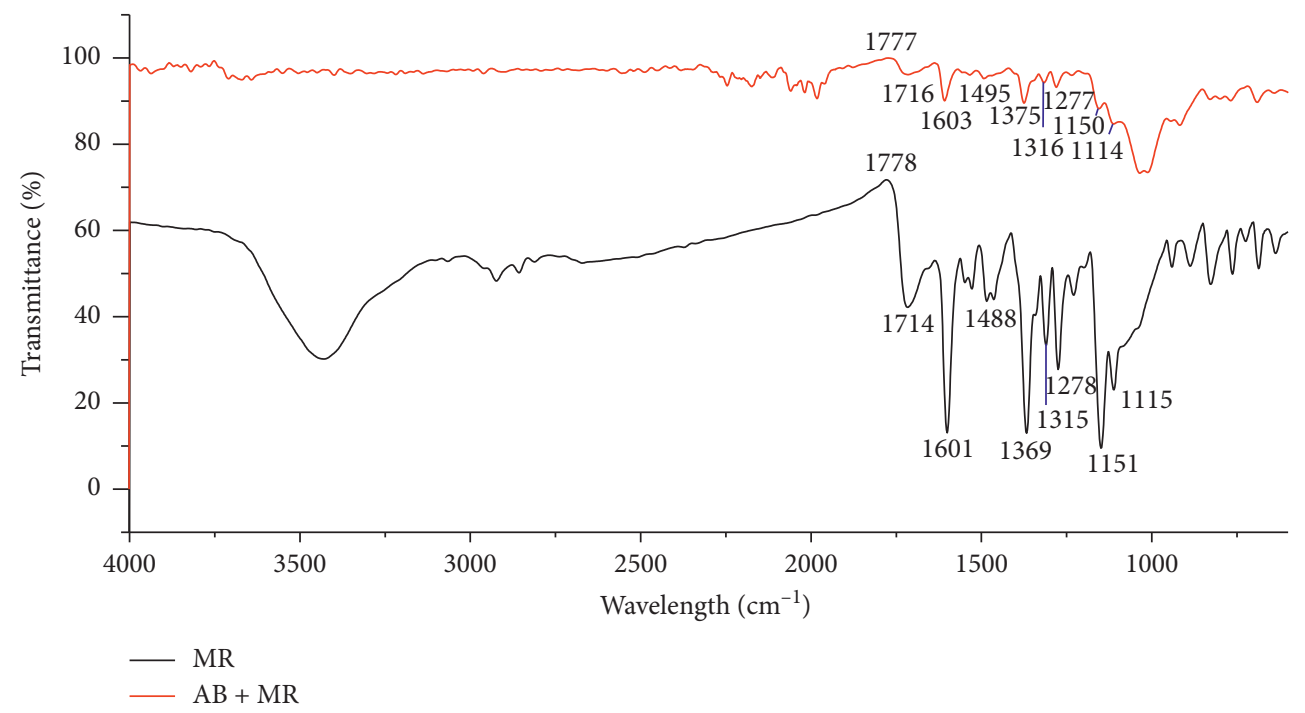

FIgURE 8: FTIR spectra of methyl red (MR) dye and after its adsorption by purified clay (MR + ANp).
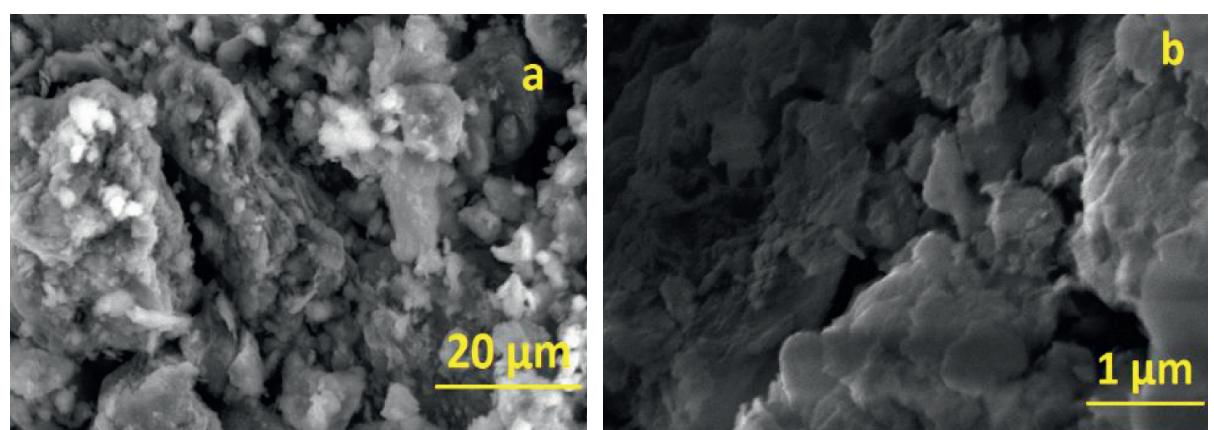

FIGURE 9: SEM image of raw clay ANb before (a) and after (b) MR-dye uptake.

Generally, adsorption of a solute is considered as monolayer adsorption; that is, the adsorption layer is one molecule in thickness with no migration of the adsorbate in the surface of adsorbent [65]. Langmuir isotherms model assumes the existence of a monolayer adsorption with homogeneity of the surface $[43,66]$. The linear form is expressed in the following equation:

$$
\frac{C_{e}}{q_{e}}=\left(\frac{1}{q_{m} K_{L}}\right)+\left(\frac{C_{e}}{q_{m}}\right)
$$



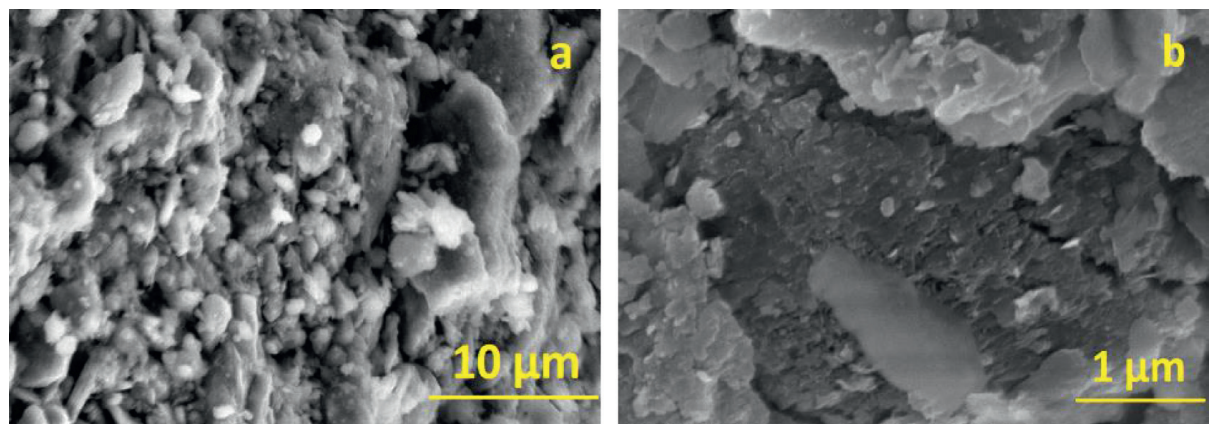

FIGURE 10: SEM image of purified clay ANp before (a) and after (b) MR-dye uptake.

where $\mathrm{q}_{\mathrm{e}}\left(\mathrm{mgg}^{-1}\right)$ is the adsorbed amount of the solute at equilibrium, $\mathrm{C}_{\mathrm{e}}\left(\mathrm{mgL}^{-1}\right)$ is the concentration of the solute at equilibrium, $\mathrm{q}_{\mathrm{m}}\left(\mathrm{mgg}^{-1}\right)$ is the maximum adsorption capacity, and $\mathrm{K}_{\mathrm{L}}\left(\mathrm{Lmg}^{-1}\right)$ is the ratio of adsorption and desorption rate constant or Langmuir parameter. Then, by plotting $\mathbf{f}\left(\mathrm{C}_{\mathrm{e}}\right)=\mathrm{C}_{\mathrm{e}} / \mathbf{q}_{\mathrm{e}}$, the value of the maximum capacity of the monolayer is determined.

It is also proposed that the solute-solid is strong enough to allow solvent-solid interactions in monolayer and there is no similarity in the following layers [67].

Freundlich isotherm model assumes that adsorption occurs on a heterogeneous surface with interaction between adsorbed molecules $[68,69]$. At equilibrium, this model is an empirical equation expressed as follows:

$$
\mathrm{q}_{\mathrm{e}}=\mathrm{C}_{\mathrm{e}}^{1 / \mathrm{n}} \mathrm{K}_{\mathrm{f}},
$$

where $\mathrm{K}_{\mathrm{f}}\left(\mathrm{Lg}^{-1}\right)$ is the ratio of adsorption capacity of the adsorbent and $\mathrm{n}$ is the heterogeneity factor $\left(\mathrm{Lg}^{-1}\right)$.

Meanwhile the linear form is given by the following equation:

$$
\operatorname{Ln} \mathbf{q}_{\mathrm{e}}=\operatorname{LnK}_{\mathrm{f}}+\frac{1}{\mathrm{n}} \operatorname{Ln} \mathrm{C}_{\mathrm{e}}
$$

This model suggests that adsorption energy is not constant but exponentially decreases upon the completion of adsorption process.

Adsorption equilibrium data were fitted to Freundlich (b, e) and Langmuir (a, d) isotherm models for ANb and ANp (Figure 11). Two model parameters that were obtained for the adsorption of the methyl red onto natural and purified clays were shown in Table 6.

At first, separation factor $R_{\mathrm{L}}$ indicated a linear adsorption $\left(R_{\mathrm{L}}=1\right)$ for natural $(\mathrm{ANb})$ and purified (ANp) clays. The intensity parameter $1 / \mathrm{n}>1$ showed that adsorption was defavorable because adsorption bonds became weak. Adsorption capacity decreases confirmed the linear adsorption process. Therefore, the best fitting results were obtained with Langmuir isotherm model. Consequently, monolayer adsorption capacity was in accordance with the experimental result for the two adsorbents (ANb and $\mathrm{ANp}$ ). Similar results were obtained in obvious studies (e.g., [54]).

Dubinin-Radushkevich (D-R) isotherm determines the energy balance of the adsorption process [70,71]. Based on this model, $\mathrm{E}$ is the energy quantity necessary to remove one molecule from the adsorbent to the infinity and the adsorption processes are classified as a physical adsorption if $\mathrm{E}<8 \mathrm{kJmol}^{-1}$ and chemical adsorption if $8<\mathrm{E}<168 \mathrm{kJmol}^{-1}$. The model has often successfully fitted high solute activities and the intermediate range of concentrations data. D-R isotherm is expressed by the following equation:

$$
\operatorname{Ln} \mathbf{q}_{\mathbf{e}}=\operatorname{Ln} V_{m}^{\prime}-K^{\prime} \varepsilon^{2},
$$

where $\mathrm{q}_{\mathrm{e}}$ is the amount of dye which is adsorbed at equilibrium time $\left(\mathrm{mgg}^{-1}\right)$ by solid matrix, $\mathrm{V}_{\mathrm{m}}^{\prime}$ is the maximum adsorption capacity $\left(\mathrm{molg}^{-1}\right), \mathrm{K}^{\prime}$ is the activity coefficient related to the adsorption energy, and $\varepsilon$ is the Polanyi potential, which is equal to

$$
\varepsilon=\mathbf{R} \operatorname{T~} \operatorname{Ln}\left(1+\frac{1}{\mathrm{C}_{\mathrm{e}}}\right)
$$

$\mathrm{R}$ is the constant of the gases $\left(\mathrm{JK}^{-1} \mathrm{~mol}^{-1}\right)$ and $\mathrm{T}$ is the temperature $(\mathrm{K})$.

Adsorption energy $\mathrm{E}\left(\mathrm{kJmol}^{-1}\right)$ is expressed by the following equation:

$$
\begin{aligned}
& \mathbf{E}=\left(-2 \mathbf{K}^{\prime}\right)^{-0.5}, \\
& \mathbf{E}=\frac{\mathbf{1}}{\mathbf{2} \boldsymbol{\beta}},
\end{aligned}
$$

it gives information on physical and chemical characteristics of adsorption.

Adsorption equilibrium data were fitted to the Dubinin-Radushkevich $(c, f)$ isotherm models for $A N b$ and $A N p$. The linear curve for the D-R isotherm obtained by tracing $\varepsilon^{2}$ as a function of $\mathrm{Ln} \mathrm{q}_{\mathrm{e}}$ was presented with the experimental data in Figure 11. Average adsorption energy calculated from $\mathrm{D}-\mathrm{R}$ isotherm confirmed that the physisorption was the dominate mechanism $\left(\mathrm{E}<8 \mathrm{kJmol}^{-1}\right)$ for two adsorbents (Table 5).

3.5. Kinetic Models. The kinetics of adsorption define the efficiency of an adsorbent. Adsorption kinetics of MR onto natural and purified were investigated using different MR concentrations $\left(30-1000 \mathrm{mgL}^{-1}\right)$. When the solution had $25^{\circ} \mathrm{C}\left( \pm 2^{\circ} \mathrm{C}\right)$ and acid $\mathrm{pH} 3$, the optimal quantity of adsorbed dye was obtained. Several models were used to fit experiment data for adsorption kinetics identification. MR adsorption 


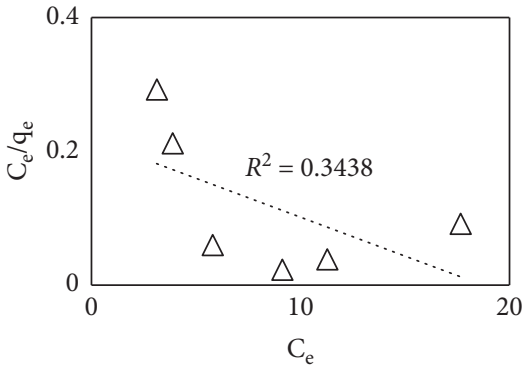

(a)

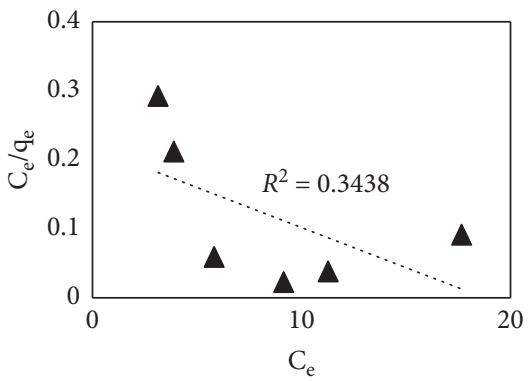

(d)

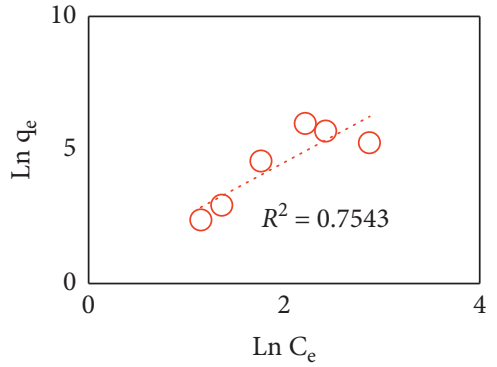

(b)

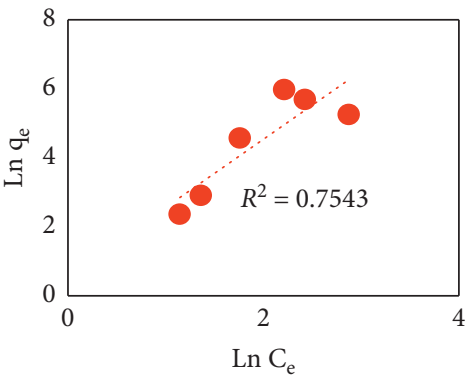

(e)

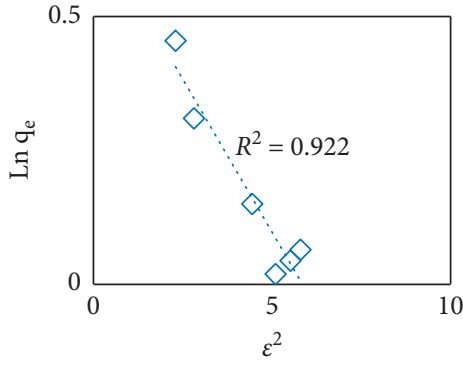

(c)

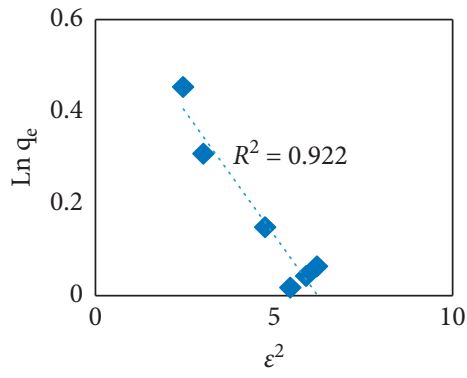

(f)

Figure 11: Isotherm models for MR-dye adsorption onto raw (ANb) and purified (ANp) clays. (a) Langmuir, (b) Freundlich, and (c) D-R for ANb; (d) Langmuir, (e) Freundlich, and (f) D-R for ANp.

TABLE 6: Langmuir, Freundlich, and Dubinin-Radushkevich (D-R) parameters.

\begin{tabular}{|c|c|c|c|c|c|c|}
\hline & \multicolumn{2}{|c|}{ Langmuir } & \multicolumn{2}{|c|}{ Freundlich } & \multicolumn{2}{|c|}{$\mathrm{D}-\mathrm{R}$} \\
\hline \multirow{4}{*}{$\mathrm{ANb}$} & Q0 $\left(\mathrm{mgg}^{-1}\right)$ & 59.180 & $\mathrm{~K}_{\mathrm{F}}\left(\mathrm{Lg}^{-1}\right)$ & 3.480 & $V^{\prime} \mathrm{m}\left(\mathrm{molg}^{-1}\right)$ & 6.529 \\
\hline & $\mathrm{K}_{\mathrm{L}}\left(\mathrm{Lmg}^{-1}\right)$ & 0.007 & $1 / \mathrm{n}$ & 2.125 & $\mathrm{~K}^{\prime}\left(\mathrm{mol}^{2} \mathrm{~kJ}^{-2}\right)$ & -0.321 \\
\hline & $R^{2}$ & 0.788 & $\mathrm{~N}$ & 0.471 & $\mathrm{E}\left(\mathrm{KJmol}^{-1}\right)$ & 1.248 \\
\hline & $R_{\mathrm{L}}$ & 0.999 & $R^{2}$ & 0.962 & & \\
\hline \multirow{4}{*}{$\mathrm{ANp}$} & Q0 $\left(\mathrm{mgg}^{-1}\right)$ & -86.207 & $\mathrm{~K}_{\mathrm{F}}\left(\mathrm{Lg}^{-1}\right)$ & 1.809 & V'm $\left(\mathrm{molg}^{-1}\right)$ & 1.954 \\
\hline & $\mathrm{K}_{\mathrm{L}}\left(\mathrm{Lmg}^{-1}\right)$ & -0.003 & $1 / \mathrm{n}$ & 1.973 & $\mathrm{~K}^{\prime}\left(\mathrm{mol}^{2} \mathrm{~kJ}^{-2}\right)$ & -0.111 \\
\hline & $R^{2}$ & 0.344 & $\mathrm{n}$ & 0.507 & $\mathrm{E}\left(\mathrm{KJmol}^{-1}\right)$ & 2.119 \\
\hline & $R_{\mathrm{L}}$ & 1.000 & $R^{2}$ & 0.754 & & \\
\hline
\end{tabular}

dynamics processes were studied by Pseudo-first-order and pseudo-second-order models. These two models describe the solute uptake rate at solid-solution interface [48] and control the resident time of adsorbate and possibilities of desorption [41, 54]. The linear form of pseudo-first-order model was explained by Lagergren equation (8):

$$
\log \left(q_{e}-q_{t}\right)=\frac{\log q_{e}-k_{1} t}{2.303}
$$

where $\mathrm{q}_{\mathrm{e}}$ and $\mathrm{q}_{\mathrm{t}}$ are the amounts of dye adsorbed $\left(\mathrm{mgg}^{-1}\right)$ on the adsorbents at the equilibrium and at time $t$.

$\mathrm{k}_{1}$ is the rate constant of adsorption $\left(\mathrm{min}^{-1}\right)$. The values of $\mathrm{k}_{1}$ were calculated by plotting $\log \left(\mathrm{q}_{\mathrm{e}}-\mathrm{q}_{\mathrm{t}}\right)$ versus time $\mathrm{t}$ (min).

Linear form of pseudo-second-order model is expressed by the following equation:

$$
\frac{t}{q_{t}}=\frac{1}{k_{2} q_{e}^{2}}+\frac{1}{q_{e} t},
$$

where $\mathrm{k}_{2}$ is the rate constant of pseudo-second-order model $\left(\mathrm{gmg}^{-1} \mathrm{~min}^{-1}\right)$. Values of $\mathrm{k}_{2}$ and $\mathrm{q}_{\mathrm{e}}$ were calculated from intercepting a linear plot of $\mathbf{t} / \mathbf{q}_{\mathbf{t}}$ versus $t$.

Linear form of the two models and their calculated parameters for both adsorbents were listed in Figures 12 and 13. Initially, removal rate of MR was rapid and then it was gradually slowed down until equilibrium state beyond which there was no significant increase. The maximum MR adsorption onto $\mathrm{ANb}$ and $\mathrm{ANp}$ (equilibrium state) was observed at $10 \mathrm{~min}$. The kinetic experimental parameters of pseudo-firstorder and pseudo-second-order models $\left(\mathrm{q}_{\mathrm{e}}\right.$ and $\left.\mathrm{q}_{\mathrm{t}}\right)$ and the rate constant of pseudo-first-order model $\left(\mathrm{k}_{1}\right.$ and $\left.R^{2}\right)$ and pseudosecond-order model $\left(\mathrm{k}_{2}\right.$ and $\left.R^{2}\right)$ were determined. The slopes and intercepts of plots of $\log \left(\mathrm{q}_{\mathrm{e}}-\mathrm{q}_{\mathrm{t}}\right)$ versus $\mathrm{t}(0-80 \mathrm{~min})$ were used to determine the first-order rate constant $\mathrm{k}_{1}$ and equilibrium adsorption density $\mathrm{q}_{\mathrm{e}}$ for $\mathrm{ANb}$ and $\mathrm{ANp}$. $\mathrm{k}_{1}$ ranges were from 0 to 0.001 for $\mathrm{ANb}$ and from -0.001 to 0.001 for $\mathrm{ANp}$ and their correlation coefficients $\left(R^{2}\right)$ ranges were 0.04-0.27 for ANb and 0.09-0.88 for ANp (Figure 12). 


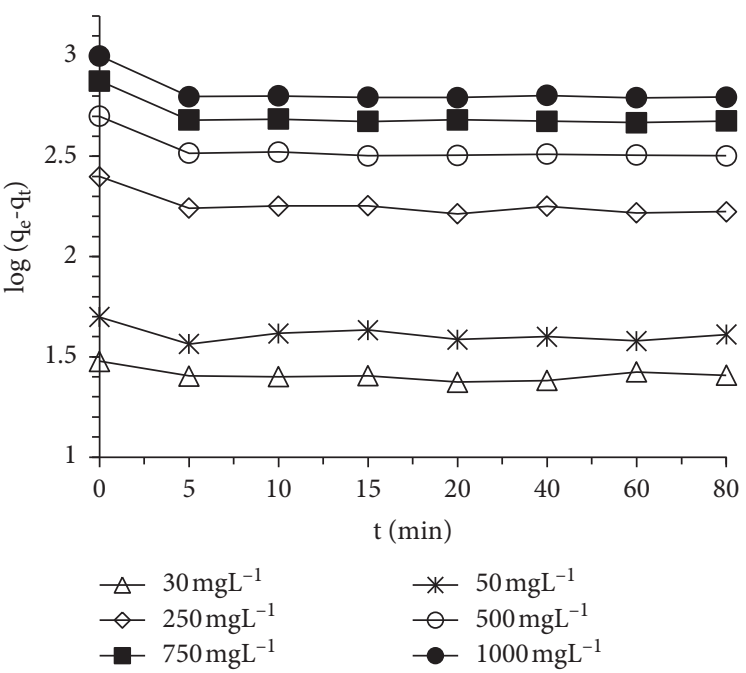

(a)

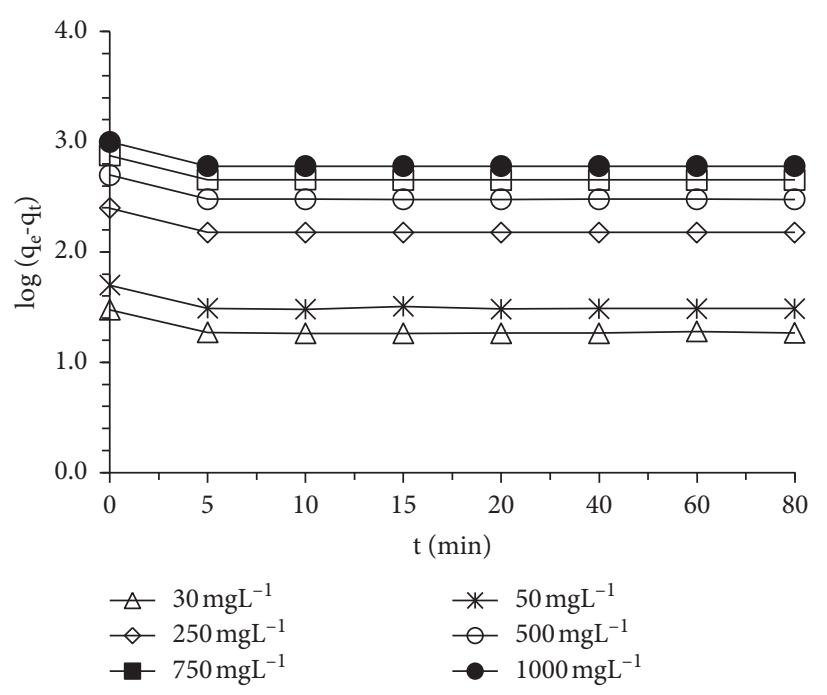

(b)

FIgUre 12: Pseudo-first-order adsorption kinetics of MR onto ANb (a) and ANp (b).

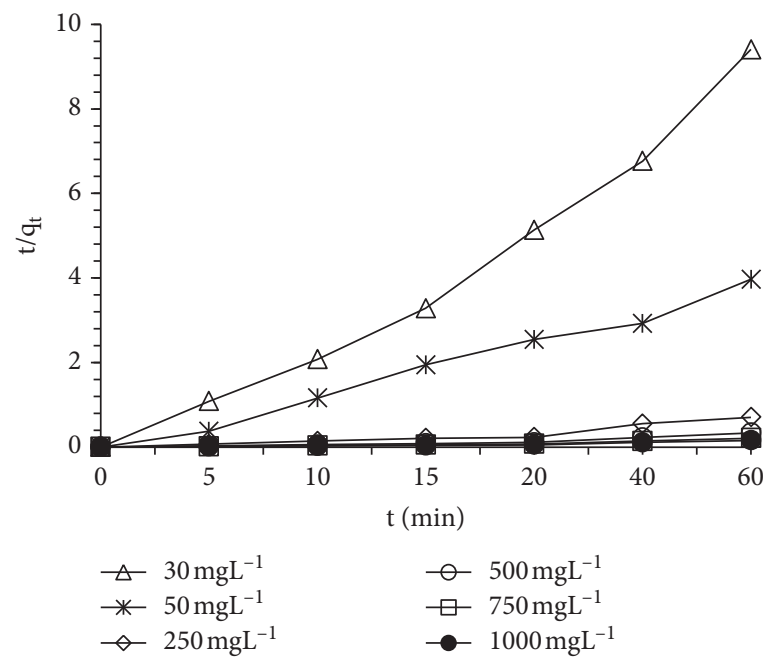

(a)

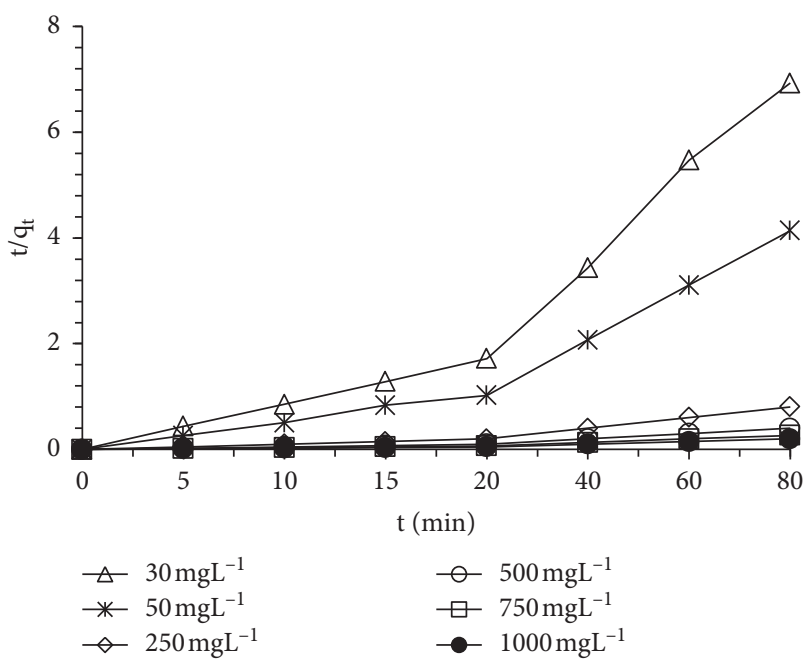

(b)

Figure 13: Pseudo-second-order adsorption kinetics of MR onto ANb (a) and ANp (b).

However, for the linear plots of $t / q_{t}$ versus $t$ for the pseudo-second-order model, the $\mathrm{k}_{2}$ ranges were from about 0.4 to $10^{5}$ for $\mathrm{ANb}$ and from about $-10^{3}$ to $34.10^{4}$ for $\mathrm{ANp}$, and $R^{2}$ values were from 0.95 to 1 for $\mathrm{ANb}$ and 1 for $\mathrm{ANp}$ (Figure 13). These experimental and calculated values showed that the adsorption of MR onto Jebel Louka clay followed the pseudo-second-order model.

3.6. Thermodynamic Study. Adsorption is a phenomenon that can be endothermic or exothermic. It depends on the adsorbent material and the nature of the adsorbed molecules $[72,73]$. Thermodynamic parameters of equilibrium adsorption reaction are standard entropy $\Delta S^{\circ}$, standard enthalpy $\Delta \mathrm{H}^{\circ}$, and standard free enthalpy $\Delta \mathrm{G}^{\circ}$ [69]. These parameters were determined using the following equations:

$$
\begin{aligned}
\mathbf{k}_{\mathrm{d}} & =\frac{\mathbf{Q}_{\mathrm{e}}}{\mathrm{C}_{\mathrm{e}}}\left(\lg ^{-1}\right), \\
\mathbf{L n k}_{\mathrm{d}} & =\frac{\Delta \mathbf{S}^{\circ}}{\mathbf{R}}-\frac{\Delta \mathbf{H}^{\circ}}{\mathbf{R T}}, \\
\Delta \mathbf{G}^{\circ} & =-\mathbf{R} \operatorname{TLnk}_{\mathrm{d}} .
\end{aligned}
$$

Calculated values of thermodynamic parameters of dye adsorption onto natural and purified clays ( $\mathrm{ANb}$ and $\mathrm{ANp}$ ) were given in Table 7. The obtained values of $\Delta \mathrm{H}^{\circ}$ at 20,30 , and $40^{\circ} \mathrm{C}$ for $\mathrm{ANb}$ and $\mathrm{ANp}$ indicated that adsorption of $\mathrm{MR}$ onto Jebel Louka clay was an endothermic process. The positive $\Delta \mathrm{S}^{\circ}$ value was for all cases about $0.07 \mathrm{kJmol}^{-1} \mathrm{~K}^{-1}$. Hence, the low positive values of entropy variations showed that there was a random interference at solid-liquid interface during the fixation of MR on the active sites of adsorbent. The negative or nil values of Gibbs free energy $\left(\Delta \mathrm{G}^{\circ}\right)$ at the three 
TABLE 7: Thermodynamic parameters of MR adsorption on ANb and ANp.

\begin{tabular}{lcccc}
\hline \multirow{2}{*}{ Adsorbents } & Temperature $\mathrm{T}\left({ }^{\circ} \mathrm{K}\right)$ & \multicolumn{3}{c}{ Thermodynamic parameters } \\
& & $\Delta \mathrm{G}^{\circ}\left(\mathrm{KJmol}^{-1}\right)$ & $\Delta \mathrm{H}^{\circ}\left(\mathrm{KJmol}^{-1}\right)$ & $\Delta \mathrm{S}^{\circ}\left(\mathrm{KJmol}^{-1} \mathrm{~K}^{-1}\right)$ \\
\hline \multirow{2}{*}{$\mathrm{ANb}$} & 293.15 & 0 & 20.20 & 0.0690 \\
& 303.15 & -6326.27 & 20.86 & 0.0688 \\
\hline \multirow{3}{*}{$\mathrm{ANp}$} & 313.15 & 0 & 21.55 & 0.0688 \\
& 293.15 & -40.40 & 20.20 & 0.0689 \\
& 303.15 & -41.73 & 0 & 0.0688 \\
& 313.15 & 0 & 0 & 0.0688 \\
\hline
\end{tabular}

TABLE 8: Yields of methyl red removed using different methods, processes, and materials.

\begin{tabular}{|c|c|c|c|}
\hline Methods & Materials (adsorbents) & $\begin{array}{c}\text { Removal } \\
\text { yields }(\%)\end{array}$ & References \\
\hline \multirow{3}{*}{ Chemical components } & Sterchamol & 0.022 & {$[20]$} \\
\hline & $\mathrm{SiO} 2$-coated $\mathrm{Fe} 3 \mathrm{O} 4$ magnetic nanoparticles & 4.95 & {$[21]$} \\
\hline & Iron oxide modified MIL-100 (Fe) & 62.5 & {$[74]$} \\
\hline \multirow{3}{*}{$\begin{array}{l}\text { Biodegradation (or } \\
\text { biodecolorization) }\end{array}$} & Staphylococcus arlettae PF4 isolated from garden soil & 2.5 & {$[18]$} \\
\hline & Saccharomyces cerevisiae ATCC 9763 & 99.1 & [19] \\
\hline & $\begin{array}{l}\text { Consortium of bacteria (mixture of bacteria): Three bacteria (Sphingomonas } \\
\text { paucimobilis, Bacillus sp., and Staphylococcus epidermidis) }\end{array}$ & 98.0 & {$[11]$} \\
\hline \multirow{7}{*}{$\begin{array}{l}\text { Hazardous materials } \\
\text { (biocomponents) }\end{array}$} & Banana pseudostem fibers & 8.85 & {$[75]$} \\
\hline & Sugarcane bagasse, pretreated with phosphoric acid (SBC) & 1.10 & {$[76]$} \\
\hline & Untreated sugarcane bagasse (SB) & 0.57 & {$[76]$} \\
\hline & NBP. neem tree hark nowder/MBP. manos tree bark nowder/IBP. locuct hean & MBP: $12 \%$ & \\
\hline & $\begin{array}{l}\text { NBP: neem tree bark powder/MBP: mango tree bark powder/LBP: locust bean } \\
\text { tree bark powder }\end{array}$ & $\begin{array}{l}\text { NBP: } 8.5 \% \\
\text { LBP: } 8 \%\end{array}$ & [77] \\
\hline & Nano-sized calcium hydroxide catalyst prepared from clam shells & 0.2 & {$[78]$} \\
\hline & Guar Gum powder & 5.76 & [47] \\
\hline \multirow{4}{*}{ Activated carbon } & Commercially available powdered activated carbon (PAC) & 4.84 & {$[76]$} \\
\hline & Annona squamosa seeds activated carbon & 4.05 & [79] \\
\hline & Oxidized multiwalled carbon nanotubes & 10.87 & {$[22]$} \\
\hline & Mesoporous-activated carbon from durian seed & 38.47 & {$[80]$} \\
\hline \multirow{2}{*}{ Zeolite commercial } & Modified zeolite commercial activated charcoal & 3.0 & {$[81]$} \\
\hline & Modified zeolite commercial activated charcoal & 0.7 & [81] \\
\hline
\end{tabular}

tested temperatures indicated the feasibility and the spontaneity of adsorption process without an induction period.

3.7. Efficiency of Jebel Louka Clay. Several methods, processes, and components were used to remove MR (Table 8). The principal objective was to define an adsorbent or a process which had the highest capacity of methyl red (MR) elimination. Chemical components, fibers of bananas, pretreated sugarcane bagasse, activated carbon, modified zeolite, and isolate or consortium bacteria were used as adsorbent or degrading tool. The best results were given by iron oxide modified MIL-100 (Fe) (62.5\%), but a long time was necessary for finishing the process and biodegradation by one consortium of three bacteria (about 99\%).

The yields of the azo dye MR removal with tested natural $(\mathrm{ANb})$ and purified clays (ANp) were $89.5 \%$ and $92.2 \%$ when the initial concentrations of MR were 30 and $50 \mathrm{mgL}^{-1}$, respectively. In these cases, biodegradation of $\mathrm{MR}$ was more effective (Figure 14). When initial MR concentrations in solutions were equal to or higher than $750 \mathrm{mgL}^{-1}$, removal yields were at least equal to bacterial biodegradation yields.

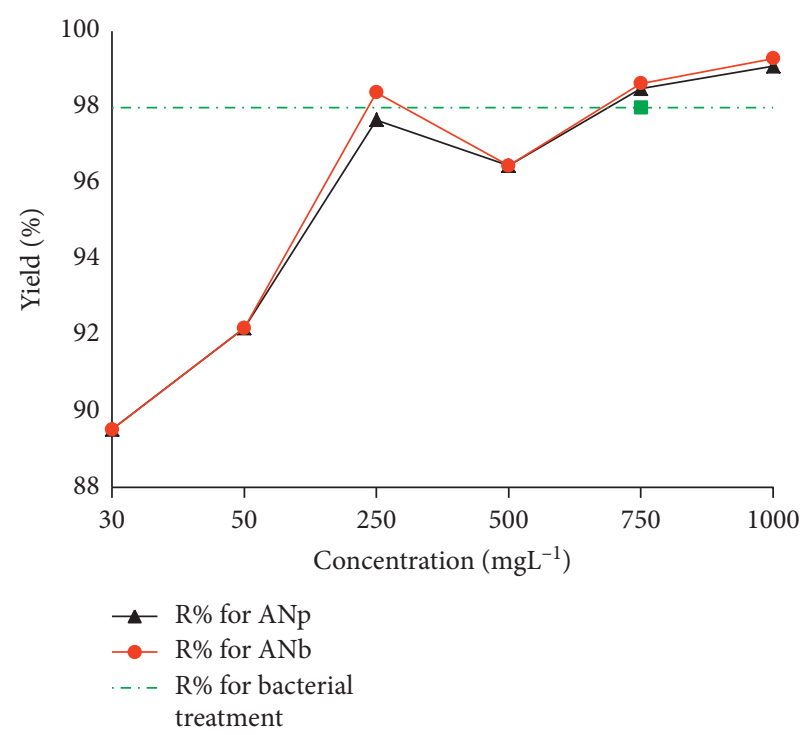

FIgURE 14: Cross between color removal (\%) of MR onto raw $(\mathrm{ANb})$ and purified $(\mathrm{ANp})$ clays and the bacterial treatment. 


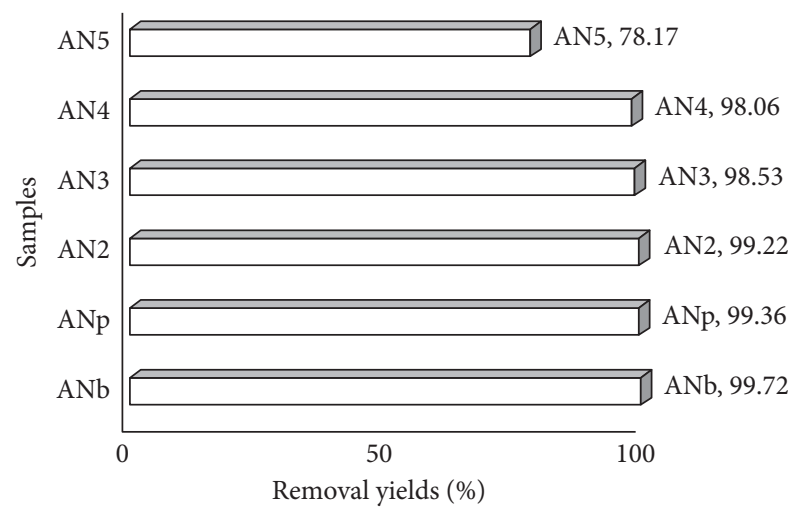

FIGURE 15: Influence of initial concentration dye and adsorbent dose onto different samples. AN2: activated clay with $0.5 \mathrm{~N} \mathrm{HCl}$; AN3: activated clay with $3 \mathrm{~N} \mathrm{HCl}$; AN4: activated clay with $2 \mathrm{~N}$ $\mathrm{H}_{2} \mathrm{SO}_{4}$; AN5: thermally activated clay $\left(500^{\circ} \mathrm{C}\right)$.

Because of low cost and facility of Jebel Louka natural clay use compared with bacterial consortium biodegradation, natural clay is better recommended for MR removal from textile wastewater.

We note that adsorption yields of chemically activated clays with $\mathrm{HCl}$ and $\mathrm{H}_{2} \mathrm{SO}_{4}$ were between $98.1 \%$ for AN4 and 99.4\% for ANp (Figure 15). Hence, chemical activation and raw material (99.7\%) gave similar results. However, thermal activation decreased adsorption capacity of treated clay (78.2\%). This decline was probably due to destruction of some adsorption active sites. However, for Lu et al. [82, 83], thermal and chemical activations improved the adsorption capacity of the material.

3.8. Desorption Studies. Desorption analyses had allowed seeing the possibility of the reuse of adsorbent or making the process more economic [84]. MR adsorbed onto natural Jebel Louka clay could be desorbed by water when the dye adsorption was by weak bonds (ion exchange or electrostatic attraction). In this case, if the clay is rejected in controlled or noncontrolled landfill the released toxic molecules could infiltrate into natural resources and have dangerous environmental impact. Therefore, it was considered that it is very important to estimate the possible desorbed amounts of MR.

Desorption tests were done using adsorbents at different $\mathrm{pH}(3,5,7,9$, and 11$)$ and ambient temperature $\left( \pm 25^{\circ} \mathrm{C}\right)$ in $100 \mathrm{~mL}$ solution of double-distilled water. At pH 3, 5, and 11, the dye amount desorbed from natural clay was more important compared to the purified clay. At $\mathrm{pH} 7$ and 9, the amount of MR released by purified clay was the most important (Figure 16). These obtained experimental results showed that the MR was easily desorbed and this pollutant could be transferred and potentially contaminated the natural resources (soil and water). Thus, rejection of saturated clays with MR can cause environmental problems. To limit the danger, the $\mathrm{pH}$ of rejected clay must be about 7 for natural clays and 11 for purified clay. In any case, we must use this saturated clay for brick making or take some measures for the isolation of this pollution source.

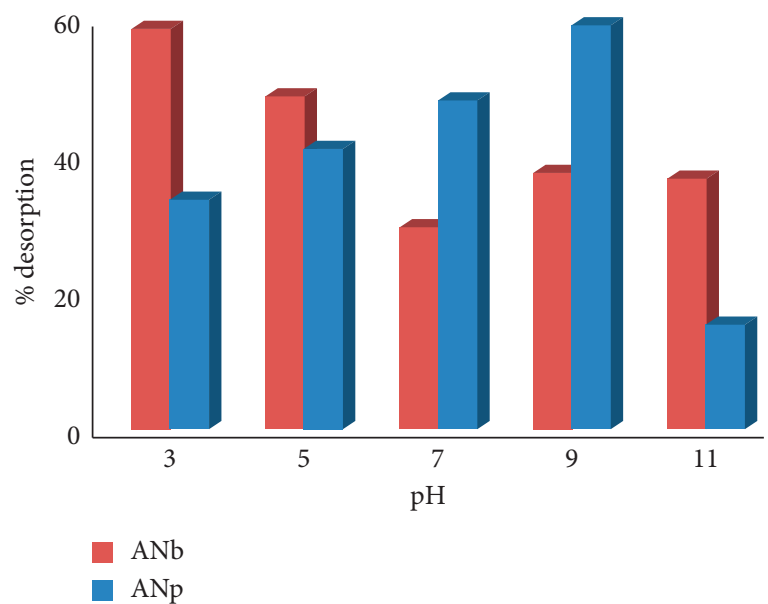

Figure 16: Desorbed yields of MR dye from raw (ANb) and purified (ANp) clays.

3.9. Comment. The used kaolinite rich clay (called Tabarka clay (TBK)) and standard kaolinite (KGa-2: the Source Clay Repository of the Clay Minerals Society) gave similar results [85]. Abidi et al. [85] advanced that an increase in the amount of adsorbed dye (qe) occurred when the concentration of RR120 dye increased from 10 to $120 \mathrm{mg} \mathrm{L}^{-1}$. The higher adsorption amount was at $\mathrm{pH}$ 3. Therefore, $\mathrm{pH}$ always played an important role in dye adsorption processes. This phenomenon was also observed when RR120 dye was adsorbed onto raw clay [86], Brilliant Green dye onto red clay [87], and acid dye onto various modified clays [88]. It was also remarked that adsorption capacity decreased with temperature increase. This effect could be explained by weakening of the adsorptive forces between the active sites of the clays and the dye molecules [85].

In order to investigate the adsorption mechanism and the nature of interaction forces between adsorbate molecules and adsorbent surfaces, Langmuir and Freundlich isotherms models were considered by all authors. They obtained also similar results. For example, Abidi et al. [85] indicated that Langmuir isotherm fitted well with their experimental data and the most suitable model to describe the experimental data was also the second-order model.

It was also observed that the desorbed dye amount from the clays was high. For example, Abidi et al. [28] showed that the desorbed dye amount from KGa was $16 \%$ and that from Tabarka clays was $18 \%$. These results were comparable to the data of this work.

\section{Conclusion}

The main conclusions were as follows: (1) the optimal adsorbed quantity of the methyl red (MR) was obtained by the use of $0.25 \mathrm{~g}$ and $0.5 \mathrm{~g}$ of raw clays and purified clays, respectively; (2) the pollutant removal increased with a decrease in $\mathrm{pH}$ for purified clay and approximately independent of temperature for raw clay; (3) the sorption isotherm showed that physisorption type and Langmuir model (good correlation coefficient $R^{2}>0.96$ ) were appropriate to the tested process; (4) the adsorption process 
was relatively rapid (about $5 \mathrm{~min}$ ) and well described by pseudo-second-order model; (5) the adsorption was endothermic and spontaneous; (6) FTIR identified that the sites of surface of adsorbent were active sites; (7) the organic matter and carbonate fractions played an important role in MR elimination; (8) raw material had better performance than the purified fraction; (9) the dye desorption confirmed the physisorption was dominant and the chemisorption was secondary produced by exchange between ions of dye and clay; (10) SEM of saturated ANb and ANp clays confirmed the disappearance of pores and spaces between clay aggregates and MR dye covered the clay surfaces.

Compared with other technologies, processes, and materials, efficiency of natural Jebel Louka clays in the methyl red removal could provide an alternative low-cost material for removal of methyl red from the textile wastewater. The presented adsorption and desorption model provided a background for pilot and industrial scale applications.

\section{Data Availability}

The data used to support the findings of this study are included within the article.

\section{Conflicts of Interest}

The authors declare that there are no conflicts of interest regarding the publication of this paper.

\section{Acknowledgments}

The authors acknowledge Tunisian Ministry of High Education and Scientific Research for its financial support and thank Pr. Simon Sheppared for the revision of the English text.

\section{References}

[1] CAR/PP, Regional Center of Activities for a Clean Production, Action Plan for the Mediterranean: Pollution Prevention in the Textile Industry in the Mediterranean Region, CAR/PP, Barcelona, Spain, 2002, http://www.cema-sa.org.

[2] S. Hammami, Degradation study of textile dyes by advanced oxidation processes: application to the depollution of industrial rejects, Ph.D. thesis, University of Marne la Vallée, Paris, France, 2010.

[3] M. Iqbal, "Vicia faba bioassay for environmental toxicity monitoring: a review," Chemosphere, vol. 144, pp. 785-802, 2016.

[4] N. de Castro-Català, M. Kuzmanovic, N. Roig et al., "Ecotoxicity of sediments in rivers: invertebrate community, toxicity bioassays and the toxic unit approach as complementary assessment tools," Science of The Total Environment, vol. 540, pp. 297-306, 2016.

[5] B. Schreiber, J. Fischer, S. Schiwy, H. Hollert, and R. Schulz, "Towards more ecological relevance in sediment toxicity testing with fish: evaluation of multiple bioassays with embryos of the benthic weatherfish (Misgurnus fossilis)," Science of the Total Environment, vol. 619-620, pp. 391-400, 2018.
[6] A. Mazhar, A. Muhammad, E. Syed et al., "Vibrio fischeri bioluminescence inhibition assay for ecotoxicity assessment: a review," Science of the Total Environment, vol. 626, pp. 1295-1309, 2018.

[7] Y. Anjaneyulu, N. Sreedhara Chary, and D. Samuel Suman Raj, "Decolourization of industrial effluents-available methods and emerging technologies-a review," Reviews in Environmental Science and Bio/Technology, vol. 4, no. 4, pp. 245-273, 2005.

[8] A. Kausar, M. Iqbal, A. Javed et al., "Dyes adsorption using clay and modified clay: a review," Journal of Molecular Liquids, vol. 256, pp. 395-407, 2018.

[9] H. B. Mansour, O. Boughzala, D. Dridi, D. Barillier, L. ChekirGhedira, and R. Mosrati, "Les colorants textiles sources de contamination de l'eau: CRIBLAGE de la toxicité et des méthodes de traitement," Revue des sciences de l'eau, vol. 24, no. 3, pp. 209-238, 2011.

[10] T. Deveci, A. Unyayar, and M. A. Mazmanci, "Production of Remazol Brilliant Blue R decolourising oxygenase from the culture filtrate of Funalia trogii ATCC 200800," Journal of Molecular Catalysis B: Enzymatic, vol. 30, no. 1, pp. 25-32, 2004.

[11] L. Ayed, S. Achour, E. Khelifi, A. Cheref, and A. Bakhrouf, "Use of active consortia of constructed ternary bacterial cultures via mixture design for Congo Red decolorization enhancement," Chemical Engineering Journal, vol. 162, no. 2, pp. 495-502, 2010.

[12] M. A. Aseel, N. Al. Abbas, and F. A. Ayad, "Kinetics and equilibrium study for the adsorption of textile dyes on coconut shell activated carbon," Arabian Journal of Chemistry, vol. 10, pp. 3381-3393, 2017.

[13] G. Chen, J. Lei, Y. Du, X. Du, and X. Chen, “A polycarboxylate as a superplasticizer for montmorillonite clay in cement: adsorption and tolerance studies," Arabian Journal of Chemistry, vol. 11, no. 6, pp. 747-755, 2018.

[14] S. Chakraborty, S. De, S. DasGupta, and J. K. Basu, "Adsorption study for the removal of a basic dye: experimental and modeling," Chemosphere, vol. 58, no. 8, pp. 1079-1086, 2005.

[15] V. J. Inglezakis, M. A. Stylianou, M. Loizidou, and A. A. Zorpas, "Experimental studies and modeling of clinoptilolite and vermiculite fixed beds for $\mathrm{Mn} 2+, \mathrm{Zn} 2+$, and Cr3+removal," Desalination and Water Treatment, vol. 57, no. 25, pp. 11610-11622, 2016.

[16] P. Verma and D. Madamwar, "Decolourization of synthetic dyes by a newly isolated strain of Serratia marcescens," World Journal of Microbiology and Biotechnology, vol. 19, no. 6, pp. 615-618, 2003.

[17] L. Ayed, A. Mahdhi, A. Cheref, and A. Bakhrouf, "Decolorization and degradation of azo dye Methyl Red by an isolated Sphingomonas paucimobilis: biotoxicity and metabolites characterization," Desalination, vol. 274, no. 1-3, pp. 272-277, 2011.

[18] P. Sarkar, A. N. M. Fakhruddin, P. M. Kamruzzaman, and A. Al-Mahin, "Decolorization of methyl red by Staphylococcus arlettae PF4 isolated from garden soil," International Journal of Environment, vol. 1, pp. 34-39, 2011.

[19] S. Vatandoostarani, T. Bagheri Lotfabad, A. Heidarinasab, and S. Yaghmaei, "Degradation of azo dye methyl red by Saccharomyces cerevisiae ATCC 9763," International Biodeterioration \& Biodegradation, vol. 125, pp. 62-72, 2017.

[20] G. Pekov and N. Petsev, "Adsorption of methyl red on sterchamol," Analytica Chimica Acta, vol. 232, pp. 413-416, 1990. 
[21] S. R. Masoud, I. Mohsen, A. Somayyeh, F. Mostafa, and J. Fattaneh, "Removal, preconcentration and determination of methyl red in water samples using silica coated magnetic nanoparticles," Journal of Applied Research in Water and Wastewater, vol. 1, pp. 6-12, 2014.

[22] M. Ghaedi and S. N. Kokhdan, "Oxidized multiwalled carbon nanotubes for the removal of methyl red (MR): kinetics and equilibrium study," Desalination and Water Treatment, vol. 49, no. 1-3, pp. 317-325, 2012.

[23] E. Eren, O. Cubuk, H. Ciftci, B. Eren, and B. Caglar, “Adsorption of basic dye from aqueous solutions by modified sepiolite: equilibrium, kinetics and thermodynamics study," Desalination, vol. 252, no. 1-3, pp. 88-96, 2010.

[24] D. Pathania, S. Sharma, and P. Singh, "Removal of methylene blue by adsorption onto activated carbon developed from Ficus carica bast," Arabian Journal of Chemistry, vol. 10, pp. 1445-1451, 2017.

[25] I. Chaari, M. Medhioub, and F. Jamoussi, "Use of clay to remove heavy metals from Jebel Chakir landfill leachate," Journal of Applied Sciences in Environmental Sanitation, vol. 6, pp. 143-148, 2011.

[26] M. Ghaedi, H. Hossainian, M. Montazerozohori et al., "A novel acorn based adsorbent for the removal of brilliant green," Desalination, vol. 281, pp. 226-233, 2011.

[27] M. H. Karaoğlu, M. Doğan, and M. Alkan, "Kinetic analysis of reactive blue 221 adsorption on kaolinite," Desalination, vol. 256, no. 1-3, pp. 154-165, 2010.

[28] N. A. bidi, J. Duplay, A. Jada et al., "Removal of anionic dye from textile industries effluents by using Tunisian clays as adsorbents: Zeta potential and streaming-induced potential measurements," Comptes Rendus Chimie, vol. 22, no. 2-3, pp. 113-125, 2019.

[29] H. Rouvier, P. Univ and M. Curie, Geology of the Tunisian Far North: tectonics and palaeogeography superimposed on the eastern end of the North Maghrebian chain, vol. 29, Annals Mines and Geology, Paris, France, 1985, Ph.D. thesis.

[30] S. Riahi, M. Soussi, K. Boukhalfa et al., "Stratigraphy, sedimentology and structure of the numidian flysch thrust belt in Northern Tunisia," Journal of African Earth Sciences, vol. 57, no. 1-2, pp. 109-126, 2010.

[31] H. W. Van der Marel, "Quantitative analysis of clay minerals and their admixtures," Contributions to Mineralogy and Petrology, vol. 12, pp. 96-138, 1966.

[32] A. Lopez Galindo, J. Torres Ruiz, and J. M. Gonzalez Lopez, "Mineral quantification in sepiolite-palygorskite deposits using X-ray diffraction and chemical data," Clay Minerals, vol. 31, no. 2, pp. 217-224, 1996.

[33] M. Delaune, M. Reiffsteck, and C. Feller, "Soil and sediment analysis using the "sedigraph 5000ET microgranulometer" comparison with the "Robinson pipette" method," Caher Orstom, Série Pedlogie, vol. XXVI, pp. 183-189, 1991.

[34] J. P. Montoroi, "Electric conductivity of soil solution and aqueous extract," Studies and Gestion of Soils, vol. 4, pp. 279-298, 1997.

[35] G. E. Rayment and F. R. Higginson, Australian Laboratory Handbook of Soil and Water Chemical Methods, Inkata Press, Melbourne, Australia, 1992.

[36] P. Anne, "Rapid determination of organic carbon in soils," Agronomic Annals, vol. 2, pp. 161-172, 1945.

[37] F. Bergaya and M. Vayer, "CEC of clays: measurement by adsorption of a copper ethylenediamine complex," Applied Clay Science, vol. 12, no. 3, pp. 275-280, 1997.
[38] G. W. Phelps and D. L. Harris, "Specific surface and dry strength by methylene blue adsorption," American Ceramic Society Bulletin, vol. 47, pp. 1146-1150, 1967.

[39] E. A. Khan, A. Shahjahan, and T. A. Khan, "Adsorption of methyl red on activated carbon derived from custard apple (Annona squamosa) fruit shell: equilibrium isotherm and kinetic studies," Journal of Molecular Liquids, vol. 249, pp. 1195-1211, 2018.

[40] J. C. Igwe, O. F. Mbonu, and A. A. Abia, "Sorption kinetics, intraparticle diffusion and equilibrium partitioning of azo dyes on great millet (Andropogon sorghum) waste biomass," Journal of Applied Sciences, vol. 7, pp. 2840-2847, 2007.

[41] A. U. Itodo, A. Abdulrahman, A. Usman, and V. C. Ugboaja, "Pseudo constants for methyl red sorption: a rate study of received and derived activated carbon," Journal of Encapsulation and Adsorption Sciences, vol. 1, no. 4, pp. 57-64, 2011.

[42] P. L. King, P. F. McMillan, and G. M. Moore, "Infrared spectroscopy of silicate glasses with application to natural systems," in Infrared Spectroscopy in Geochemistry, Exploration Geochemistry and Remote Sensing, Short Course Series 33, P. King, M. Ramsey, and G. Swayze, Eds., pp. 93-133, Mineralogical Association of Canada, Québec, Canada, 2004.

[43] I. Langmuir, "The adsorption of gases on plane surfaces of glass, mica and platinum," Journal of the American Chemical Society, vol. 40, no. 9, pp. 1361-1403, 1918.

[44] M. Doğan, M. Alkan, O. Demirbas, Y. Ozdemir, and C. Ozmetin, "Adsorption kinetics of maxilon blue GRL onto sepiolite from aqueous solutions," Chemical Engineering Journal, vol. 124, no. 1-3, pp. 89-101, 2006.

[45] S. Rengaraj, K.-H. Yeon, S.-Y. Kang, J.-U. Lee, K.-W. Kim, and S.-H. Moon, "Studies on adsorptive removal of $\mathrm{Co}(\mathrm{II}), \mathrm{Cr}(\mathrm{III})$ and $\mathrm{Ni}(\mathrm{II})$ by IRN77 cation-exchange resin," Journal of Hazardous Materials, vol. 92, no. 2, pp. 185-198, 2002.

[46] K. A. Bennani, B. Mounir, M. Hachkar, M. Bakasse, and A. Yaacoubi, "Elimination of the basic dye "methylene blue" in aqueous solution by Safi clay," Water Science Journal, vol. 23, pp. 375-388, 2015.

[47] E. Errais, Surface reactivity of natural clays: study of the adsorption of anionic dyes, Ph.D. thesis, University of Strasbourg, Strasbourg, France, 2011.

[48] R. Saxena and S. Sharma, "Adsorption and kinetic studies on the removal of methyl red from aqueous solutions using low-cost adsorbent: guargum powder," International Journal Of Scientific and Engineering Research, vol. 7, pp. 675-683, 2016.

[49] B. Karagozoglu, M. Tasdemir, E. Demirbas, and M. Kobya, "The adsorption of basic dye (astrazon blue FGRL) from aqueous solutions onto sepiolite, fly ash and apricot shell activated carbon: kinetic and equilibrium studies," Journal of Hazardous Materials, vol. 147, no. 1-2, pp. 297-306, 2007.

[50] M. Laabd, E. Abdelhadi, Ch. Hafsa, A. Nouh, M. Bazzaoui, and A. Albourine, "“Etude cinétique et thermodynamique de l'adsorption des colorants monoazoïques sur la polyaniline," Journal of Materials and Environnemental Science, vol. 6, pp. 1049-1059, 2015.

[51] O. Bouras, The adsorbent properties of organophilic bridged clays: synthesis and characterization, Ph.D. thesis, University of Limoges, Limoges, France, 2003.

[52] N. C. G. Tan, A. v. Leeuwen, E. M. v. Voorthuizen et al., "Fate and biodegradability of sulfonated aromatic amines," Biodegradation, vol. 16, no. 6, pp. 527-537, 2005. 
[53] M. Hasnain Isa, L. Siew Lang, F. A. H. Asaari et al., "Low cost removal of disperse dyes from aqueous solution using palm ash," Dyes and Pigments, vol. 74, no. 2, pp. 446-453, 2007.

[54] Q. Y. Yue, Q. Li, Y. Su, B. Y. Gao, and J. Li, "Two-step kinetic study on the adsorption and desorption of reactive dyes on cationic polymer/bentonite," Journal of Hazardous Materials, vol. 165, pp. 1170-1178, 2009.

[55] T. K. Sen and D. Gomez, "Adsorption of zinc (Zn2+) from aqueous solution on natural bentonite," Desalination, vol. 267, no. 2-3, pp. 286-294, 2011.

[56] E. Wibowo, M. Rokhmat, Sutisna, A. M. Khairurrijal, and M. Abdullah, "Reduction of seawater salinity by natural zeolite (clinoptilolite): adsorption isotherms, thermodynamics and kinetics," Desalination, vol. 409, pp. 146-156, 2017.

[57] R. Huang, B. Wang, B. Yang, D. Zheng, and Z. Zhang, "Equilibrium, kinetic and thermodynamic studies of adsorption of Cd(II) from aqueous solution onto HACC-bentonite," Desalination, vol. 280, no. 1-3, pp. 297-304, 2011.

[58] J.-M. Chern and C.-Y. Wu, "Desorption of dye from activated carbon beds: effects of temperature, $\mathrm{pH}$, and alcohol," Water Research, vol. 35, no. 17, pp. 4159-4165, 2001.

[59] L. Wang, J. Zhang, and A. Wang, "Removal of methylene blue from aqueous solution using chitosan-g-poly (acrylic acid)/ montmorillonite superadsorbent nanocomposite," Colloids and Surfaces A: Physicochemical and Engineering Aspects, vol. 322, no. 1-3, pp. 47-53, 2008.

[60] L. Wang, J. Zhang, and A. Wang, "Fast removal of methylene blue from aqueous solution by adsorption onto chitosan-gpoly (acrylic acid)/attapulgite composite," Desalination, vol. 266 , no. 1-3, pp. 33-39, 2011.

[61] K. Bhattacharyya and A. Sarma, "Adsorption characteristics of the dye, Brilliant Green, on Neem leaf powder," Dyes and Pigments, vol. 57, no. 3, pp. 211-222, 2003.

[62] O. Hamdaoui, "Batch study of liquid-phase adsorption of methylene blue using cedar sawdust and crushed brick," Journal of Hazardous Materials, vol. 135, no. 1-3, pp. 264-273, 2006.

[63] M. J. Reis, F. Silvério, J. Tronto, and J. B. Valim, "Effects of pH, temperature, and ionic strength on adsorption of sodium dodecyl benzenesulfonate into $\mathrm{Mg}-\mathrm{Al}-\mathrm{CO}_{3}$ layered double hydroxides," Journal of Physics and Chemistry of Solids, vol. 65, no. 2-3, pp. 487-492, 2004.

[64] J. Coates, "Interpretation of infrared spectra," in A Practical Approach in Encyclopedia of Analytical Chemistry, R. A. Meyers, Ed., pp. 10815-10837, John Wiley \& Sons Ltd., Chichester, UK, 2000.

[65] M. Laabd, A. El Jaouhari, H. Chafai, N. Aarab, M. Bazzaoui, and A. Albourine, "Kinetics and thermodynamic study of the adsorption of monoazo dyes on polyaniline," Journal of Materials Science, vol. 6, pp. 1049-1059, 2015.

[66] K. Y. Foo and B. H. Hameed, "Insights into the modeling of adsorption isotherm systems," Chemical Engineering Journal, vol. 156, no. 1, pp. 2-10, 2010.

[67] V. M. Vučurović, N. Radojka, Razmovski, and M. N. Tekic, "Methylene blue (cationic dye) adsorption onto sugar beet pulp: equilibrium isotherm and kinetic studies, short communication," Journal of the Taiwan Institute of Chemical Engineers, vol. 43, pp. 108-111, 2012.

[68] N. Bougdah, "Study of the adsorption of organic micropolluants on bentonite," M.S. thesis, University of Skikda, Skikda, Algeria, 2007.

[69] H. Z. Freundlich, "Over the adsorption in solution," Journal of Physical Chemistry A, vol. 57, pp. 385-470, 1906.
[70] N. Fayoud, S. A. Younssi, S. Tahiri, and A. Albizane, "Kinetics and thermodynamic study of the adsorption of methylene blue on wood ashes," Journal of Materials Science, vol. 6, pp. 3295-3306, 2015.

[71] F. Maather, A. Sawalha, R. Jose et al., "Thermodynamic and isotherm studies of the biosorption of $\mathrm{Cu}(\mathrm{II}), \mathrm{Pb}(\mathrm{II})$, and $\mathrm{Zn}$ (II) by leaves of saltbush (Atriplex canescens)," Journal of Chemical Thermodynamics, vol. 39, no. 3, pp. 488-492, 2007.

[72] O. Hamdaoui and E. Naffrechoux, "Modeling of adsorption isotherms of phenol and chlorophenols onto granular activated carbonPart I. Two-parameter models and equations allowing determination of thermodynamic parameters," Journal of Hazardous Materials, vol. 147, no. 1-2, pp. 381-394, 2007.

[73] G. Rytwo and E. Ruiz-Hitzky, "Enthalpies of adsorption of methylene blue and crystal violet to montmorillonite," Journal of Thermal Analysis and Calorimetry, vol. 71, no. 3, pp. 751759, 2003.

[74] S. Dadfarnia, A. M. Haji Shabani, S. E. Moradi, and S. Emami, "Methyl red removal from water by iron based metal-organic frameworks loaded onto iron oxide nanoparticle adsorbent," Applied Surface Science, vol. 330, pp. 85-93, 2000.

[75] M. R. H. M. Haris and K. Sathasivam, "The removal of methyl red from aqueous solutions using banana pseudo stem fibers American," Journal of Applied Sciences, vol. 6, no. 9, pp. 1690-1700, 2009.

[76] S. A. Saad, K. M. Isa, and R. Bahari, "Chemically modified sugarcane bagasse as a potentially low-cost biosorbent for dye removal," Desalination, vol. 264, no. 1-2, pp. 123-128, 2010.

[77] P. E. Dim, "Adsorption of methyl red and methyl orange using different tree bark powder," Academic Research International, vol. 4, pp. 330-338, 2013.

[78] R. B. Narayan, B. Goutham, B. Srikanth, and K. P. Gopinath, "A novel nano-sized calcium hydroxide catalyst prepared from clamshells for the photo degradation of methyl red dye," Journal of Environmental Chemical Engineering, vol. 6, no. 9, pp. 3640-3647, 2016.

[79] T. Santhi, S. Manonmani, and T. Smitha, "Removal of methyl red from aqueous solution by activated carbon prepared from the Annona squmosa seed by adsorption," Chemical Engineering Research Bulletin, vol. 14, no. 1, pp. 11-18, 2010.

[80] M. A. Ahmad, N. Ahmad, and O. S. Bello, "Modified durian seed as adsorbent for the removal of methyl red dye from aqueous solutions," Applied Water Science, vol. 5, no. 4, pp. 407-423, 2015.

[81] Z. Ioannou, C. Karasavvidis, A. Dimirkou, and V. Antoniadis, "Adsorption of methylene blue and methyl red dyes from aqueous solutions onto modified zeolites," Water Science and Technology, vol. 67, no. 5, pp. 1129-1136, 2013.

[82] H. Lu, Q. Zhang, Y. Dong, J. Li, and X. Zhang, "The adsorption capacity, pore structure, and thermal behavior of the modified clay containing SSA," vol. 2016, Article ID 9894657 , 7 pages, 2016.

[83] M. A. Usman, V. I. Kkwueme, T. O. alaje, and A. O Mohammed, "Characterization, acid activation, and bleaching performance of Ibeshe clay, Lagos, Nigeria," ISRN Ceramics, vol. 2012, Article ID 658508, 5 pages, 2012.

[84] P. Sivakumar and P. N. Palanisamy, "Adsorption studies of basic red 29 by a non-conventional activated carbon prepared from Euphorbia antiquorum L," International Journal of Chemical Technology Research, vol. 1, pp. 502-510, 2009.

[85] N. Abidi, J. Duplay, A. Jada et al., "Toward the understanding of the treatment of textile industries' effluents by clay: 
adsorption of anionic dye on kaolinite," Arabian Journal of Geosciences, vol. 10, no. 16, p. 373, 2017.

[86] E. Errais, J. Duplay, M. Elhabiri et al., “Anionic RR120 dye adsorption onto raw clay: surface properties and adsorption mechanism," Colloids and Surfaces A: Physicochemical and Engineering Aspects, vol. 403, pp. 69-78, 2012.

[87] M. S. U. Rehman, M. Munir, M. Ashfaq et al., "Adsorption of brilliant green dye from aqueous solution onto red clay," Chemical Engineering Journal, vol. 228, pp. 54-62, 2013.

[88] Z. Bouberka, S. Kacha, M. Kameche, S. Elmaleh, and Z. Derriche, "Sorption study of an acid dye from an aqueous solutions using modified clays," Journal of Hazardous Materials, vol. 119, no. 1-3, pp. 117-124, 2005. 